\title{
事務所ビルの設備のライフサイクル環境負荷原単位 LCI DATA ON ELECTRICAL AND MECHANICAL FACILITIES OF OFFICE BUILDINGS
}

\author{
伊香賀 俊治*，外 岡 豊** \\ Toshiharu IKAGA and Yutaka TONOOKA
}

\begin{abstract}
Environmental burdens through building life cycle are induced by almost all industries such as raw material manufacturers, fabricators, traders and other service industries. Better way to carry out LCA of building practically is to develop LCI data based on the input-output table and other statistical data. This paper describes $\mathrm{LCCO}_{2}, \mathrm{LCSOx}$ LCNOx and LCE on office building facilities based on the 1990 Input-Output Table of Japan and other statistical data. This simplified LCA method and its database are useful for designers to reduce environmental burdens for sustainable society.
\end{abstract}

Keywords : Input-Output Table, Life Cycle Assessment, Environmental Burden, Building Facility 産業連関表、ライフサイクルアセスメント、環境負荷、建築設備

\section{1. はじめに}

建築物は、多種多様な製品とサービスによって建設・運用される 一品生産品である。このため、大量生産される他の工業製品のよう に、詳細なライフサイクルアセスメント (LCA : ISO14040s - 1997.6) を実施することは時間的にも経済的にも困難であり、設計初期段階 に使える実用的な LCA 手法と環境負荷原単位の整備が求められて いる。そのための有力な手法のひとつとして、産業連関表 ${ }^{19)}$ 等の統

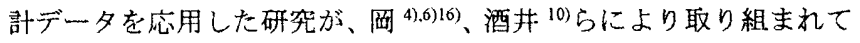
きた。筆者らも 1990 年度より始まった日本建築学会＼cjkstart建築と地球缺 境特別研究委員会での活動を契機として、1985 年および 1990 年産 業連関表等を利用した環境負荷原単位の整備に取り組んできたとこ ろである 1 3)。ISO14040 規格では、LCAの検討目的とそれに見合っ た境界条件の明示を求めており、建勧関連凟機材の噮境負荷原単位 が、国内分／海外分、消費支出分／固定資本形成分、生産段階分／ 流通段階分／最終消費段階分など、境界条件別に整理されているこ とが望ましい。また、建築・設備の詳細仕様が決まっていない設計 初期段階に、実用的な LCA を実施するために、建物用途別・規模別 工事害績統計 23)、産業連関表等の各種統計データを利用した標淮的 な電気・空調・衛生・昇降機設備の $\mathrm{LCCO}_{2} 、$ LCSO x、LCNO x、 LCE 原巣位が整備されていることが有用と考皇た。
本報では、事務所ビルを対象として、これらの分析方法と結果を 報告する。

\section{2. 罢境鿓荷原単位の作成方法 \\ 2.1 国内と海外の環境争荷原単位}

1990 年の 405 産業部門別直接環境負荷ベクトルE (405 列)には、

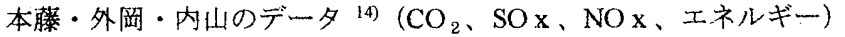
を利用した。また、国産品に置き換えると誤差が大きい5品目（原 油、LNG、石炭、アルミ地金、鉄鉣石）については海外での直接環 境負荷ベクトル $\varepsilon_{\boldsymbol{m}}$ を与え、それ以外の部門については、輸入品を 国産品に置き換えることとし、(1)式で、生産者価格あたり環境負荷 原単位を算出した。な㧍、(1)式の第1項が国産財の環境負荷を、第 2 項が国産財と仮定した輸入財の環境負荷を、第 3 項が国産品と仮 定しない輸入財（原油、LNG、石炭、アルミ地金、鉄鉣石）の環境 負荷を表している。

$$
\begin{aligned}
\varepsilon_{d} & =\mathbf{E}\left[I-\left(A_{d}+A_{m}{ }^{\prime \prime}\right)\right]^{-1}+\varepsilon_{m} A_{m}{ }^{\prime}\left[I-\left(A_{d}+A_{m}{ }^{\prime}\right)\right]^{-1} \\
& =\mathbf{E}\left(I-A_{d}\right)^{-1} \\
& +\mathbf{E}\left\{\left[I-\left(A_{d}+A_{m}{ }^{\prime \prime}\right)\right]^{-1}-\left(I-A_{d}\right)^{-1}\right\} \\
& +\varepsilon_{m} A_{m} A^{\prime}\left[I-\left(A_{d}+A_{m}{ }^{\prime}\right)\right]^{-1}
\end{aligned}
$$

* 東京大学生産技術研究所 助教授・工修

$* *$ 埼玉大学経済学部社会環境設計学科 教授・工博
Assoc. Prof., Institute of Industrial Science, University of Tokyo, M. Eng. Prof., Dept. of Social Environment Planning, Faculty of Economics, Saitama University, Dr. Eng. 
$\varepsilon$ d：生産者価格あたり環境負荷原単位ベクトル $(1 \times 405)$

E：国内生産額亦たり直接環境負荷べクトル $(1 \times 405)$

$\varepsilon_{\mathrm{m}}$ : 輸入財の生産者価格あたり直接環境負荷ベクトル $(1 \times 405)$

$\boldsymbol{A}_{d}$ ：国産財投入係数行列 $(405 \times 405)$

$\mathbf{A}_{\mathbf{m}}{ }^{\prime}$ ：国産財と仮定しない輸入財の投入係数行列 $(405 \times 405)$

$\mathbf{A}_{\mathbf{m}}{ }^{\prime}$ ：国産財と仮定した輸入財の投入保数行列 $(405 \times 405)$

I : 単位行列 $(405 \times 405)$

1990 年産業連関表の取引基本表は、527 行 $\times 411$ 列の長方行列で あるため、部門統合を行って $405 \times 405$ 部門の正方行列とした。また、 屏、副産物をマイナス投入のままとしておくと、非現害的な誘発が 生ずることになるため、これらの取引はないものとした。

\section{2 固定資本形成に伴う環境負荷}

製品やサービスを生み出すためには、原材料や加工・運搬エネル ギーなど毎年の消費支出分のほかに、数年〜数十年にわたって使い 続けられる生産設備や建物等の固定資本が必要である。ある年（例 えば 1990 年）の製品の製造・流通には、その年以前に、每年形成さ れてきた固定資本が奇与しているので、同じ年（1990 年）の固定資 本形成マトリックスを代表させて利用するという点では理論的には 問題があるが、固定資本マトリックス(公的、民間)を利用し、便宜 的に製品・サービスの生産に必要な固定資本(耐用年数 1 年以上かつ 購入価格 20 万以以上の建物、生産設備等)分を含めた。特定の産業 部門に割り付けるのが適当でないと考えられる道路、住宅、環境衛

表 1 購入者価格あたり理境負荷原単位（1990 年産業逨関表を利用、資本形成含む、海外波及含吉）

\begin{tabular}{|c|c|c|c|c|c|c|c|c|c|c|c|}
\hline \multirow[t]{2}{*}{ 行コード } & \multirow[t]{2}{*}{ 行部門名称 } & \multirow[t]{2}{*}{$\begin{array}{c}\text { 購入単価 } \\
(\text { (円 } / \mathrm{kg})\end{array}$} & \multirow[t]{2}{*}{ 単位 } & \multicolumn{2}{|c|}{$\begin{array}{c}\text { エネルギー消費原単位 } \\
(\mathrm{MJ} / \text { 平円 })\end{array}$} & \multicolumn{2}{|c|}{$\begin{array}{l}\mathrm{CO}_{2} \text { 排出原単位 } \\
\left(\mathrm{kg}-\mathrm{CO}_{2} / 千 円\right)\end{array}$} & \multicolumn{2}{|c|}{$\begin{array}{c}\mathrm{SOx} \text { 排出原単位 } \\
\left(\mathrm{g}-\mathrm{SO}_{2} / \text { 千円 }\right)\end{array}$} & \multicolumn{2}{|c|}{$\begin{array}{l}\text { NOx排出原単位 } \\
\left(\mathrm{g}-\mathrm{NO}_{2} / \text { 千円 }\right)\end{array}$} \\
\hline & & & & 生産段階 & 流通段階 & 生產段階 & 流通段階 & 生産段階 & 流通段階 & 生産段階 & 流通段階 \\
\hline 2072011 & 淕料 & 428.713 & 田 $/ \mathrm{kg}$ & 81.533 & 5.101 & 5.355 & 0.335 & 7.232 & 0.580 & 12.122 & 1.225 \\
\hline 2079021 & ゼラチン・接着威 & 407.340 & H/ kg & 99.354 & 3.473 & 6.336 & 0.227 & 8.275 & 0.427 & 12.912 & 0.918 \\
\hline 2211011 & ブラスチックフルム・シー1 & 501.285 & 田 $/ \mathrm{kg}$ & 75.472 & 4.013 & 4.695 & 0.263 & 6.472 & 0.466 & 10.105 & 0.988 \\
\hline 2211012 & プラスチ外板・管・棒 & 613.407 & $\mathrm{~m} / \mathrm{kg}$ & 79.372 & 2.980 & 4.937 & 0.196 & 6.805 & 0.379 & 10.626 & 0.819 \\
\hline 2211013 & 7.ラスチック発泡品 & 656.980 & m/kg. & 77.024 & 3.604 & 4.791 & 0.236 & 6.605 & 0.432 & 10.312 & 0.919 \\
\hline 2211015 & 強化プラスチック製品 & 991.877 & $\mathrm{M} / \mathrm{kg}$ & 77.138 & 3.348 & 4.797 & 0.217 & 6.614 & 0.371 & 10.327 & 0.775 \\
\hline 2511011 & 板ガフス & 203.825 & M $/ \mathrm{kg}$ & 73.947 & 6.148 & 4.598 & 0.404 & 7.546 & 0.787 & 16.195 & 1.704 \\
\hline 2512011 & ガフス繊維・同製品 & 410.713 & $\mathrm{M} / \mathrm{kg}$ & 94.109 & 4.848 & 5.798 & 0.319 & 7.564 & 0.686 & 15.954 & 1.524 \\
\hline 2521011 & セxント & 13.678 & $\mathrm{M} / \mathrm{kg}$ & 320.304 & 25.353 & 59.669 & 1.716 & 16.030 & 6.064 & 114.672 & 14.092 \\
\hline 2522011 & 生コンクリート & 6.860 & ल $/ \mathrm{kg}$ & 115.022 & 9.968 & 17.182 & 0.659 & 8.750 & 1.218 & 39.698 & 2.613 \\
\hline 2523011 & 七メント製品 & 23.930 & $\mathrm{H} / \mathrm{kg}$ & 72.504 & 7.391 & 7.700 & 0.488 & 6.876 & 0.917 & 19.113 & 1.972 \\
\hline 2531011 & 建設角陶磁器 & 266.387 & $\boxplus / \mathrm{kg}$ & 58.447 & 5.387 & 3.626 & 0.355 & 4.698 & 0.620 & 7.295 & 1.313 \\
\hline 2621011 & 普通鐡形鋮 & 71.090 & 由/ kg & 272.569 & 4.923 & 17.997 & 0.327 & 34.499 & 0.908 & 70.121 & 2.065 \\
\hline 2621014 & 普通鍂小棒 & 61.325 & 円 $/ \mathrm{kg}$ & 282.628 & 4.250 & 18.661 & 0.284 & 35.771 & 0.864 & 72.709 & 1.990 \\
\hline 2622011 & 普通金翼金管 & 112.637 & M $/ \mathrm{kg}$ & 189.868 & 4.589 & 12.593 & 0.306 & 21.941 & 0.885 & 43.432 & 2.025 \\
\hline 2622012 & 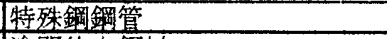 & 212.810 & 西 $/ \mathrm{kg}$ & 185.056 & 5.060 & 12.273 & 0.335 & 21.387 & 0.916 & 42.331 & 2.078 \\
\hline 2623011 & 盆間仕上鍼材 & 115.465 & $\mathrm{M} / \mathrm{kg}$ & 200.655 & 4.359 & 13.222 & 0.291 & 24.412 & 0.872 & 45.851 & 2.002 \\
\hline 2623021 & めっき鎡杜 & 117.415 & 由 $/ \mathrm{kg}$ & 150.656 & 5.339 & 10.195 & 0.354 & 16.378 & 0.934 & 30.080 & 2.112 \\
\hline 2631021 & 鋒鉄管 & 241.598 & 円 $/ \mathrm{kg}$ & 121.370 & 4.763 & 9.478 & 0.317 & 12.451 & 0.895 & 19.639 & 2.043 \\
\hline 2631031 & 鋳鉄品 & 227.362 & $\mathrm{M} / \mathrm{kg}$ & 166.574 & 4.399 & 14.421 & 0.292 & 18.938 & 0.873 & 28.152 & 2.007 \\
\hline 2711021 & 劉(はんだ) & 260.436 & $\mathrm{M} / \mathrm{kg}$ & 118.441 & 2.456 & 10.514 & 0.161 & 12.867 & 0.318 & 14.701 & 0.688 \\
\hline 2721011 & 鍋電線 & 1601.476 & M/kg & 67.461 & 3.629 & 4.243 & 0.240 & 10.406 & 0.464 & 10.151 & 1.002 \\
\hline 2721012 & アルミ電線 & 820.457 & $\mathrm{M} / \mathrm{kg}$ & 67.478 & 3.660 & 4.245 & 0.242 & 10.410 & 0.471 & 10.153 & 1.018 \\
\hline 2721013 & ケープル & 1731.662 & 丹 $/ \mathrm{kg}$ & 67.095 & 3.457 & 4.219 & 0.228 & 10.349 & 0.415 & 10.095 & 0.882 \\
\hline 2722011 & 伸銅嵒 & 722.402 & M/ kg & 65.291 & 2.465 & 4.154 & 0.163 & 7.407 & 0.332 & 7.865 & 0.723 \\
\hline 2722021 & アルミ圧延製嵒 & 621.905 & 雨 $/ \mathrm{kg}$ & 223.854 & 2.509 & 12.663 & 0.165 & 82.398 & 0.309 & 54.561 & 0.698 \\
\hline 2722031 & 非鉄金属鋳鉎造品 & 1113.603 & B $/ \mathrm{kg}$ & 155.589 & 2.157 & 9.226 & 0.143 & 49.315 & 0.291 & 34.084 & 0.636 \\
\hline 2812011 & 建築用金属製品 & 940.413 & $\mathrm{M} / \mathrm{kg}$ & 80.606 & 6.218 & 4.876 & 0.409 & 17.744 & 0.728 & 17.478 & 1.545 \\
\hline 2891011 & ガス・石油機器及ひ暖呞房機器 & 596.318 & 月/ $\mathrm{kg}$ & 68.893 & 5.948 & 4.397 & 0.384 & 8.367 & 0.590 & 14.292 & 1.166 \\
\hline 2899011 & ボルトナットスプソグ & 459.781 & $\mathrm{~m} / \mathrm{kg}$ & 92.119 & 3.380 & 5.893 & 0.224 & 9.982 & 0.439 & 18.684 & 0.993 \\
\hline 2899021 & 金属製容器及び製缶板金製品 & 592.280 & $\mathrm{M} / \mathrm{kg}$ & 82.798 & 4.558 & 5.313 & 0.301 & 10.167 & 0.632 & 16.991 & 1.398 \\
\hline 2899031 & 配管工事付属品 & 854.807 & $\mathrm{~m} / \mathrm{kg}$ & 75.962 & 2.772 & 4.619 & 0.182 & 7.745 & 0.319 & 12.952 & 0.707 \\
\hline 2899092 & 金属線製品 & 768.360 & M/kg & 76.709 & 3.344 & 4.655 & 0.219 & 8.979 & 0.385 & 13.891 & 0.847 \\
\hline 3011011 & ボイ & 1102.120 & 历 $/ \mathrm{kg}$ & 57.855 & 2.838 & 3.744 & 0.187 & 6.357 & 0.318 & 10.866 & 0.667 \\
\hline 3011031 & 原動機 & 1133.689 & 円 $/ \mathrm{kg}$ & 64.182 & 2.859 & 4.245 & 0.188 & 7.731 & 0.318 & 11.812 & 0.673 \\
\hline 3012011 & 運搬楼械 & 1083.349 & $\mathrm{I} / \mathrm{kg}$ & 54.762 & 3.938 & 3.570 & 0.258 & 6.066 & 0.416 & 10.461 & 0.860 \\
\hline 3013011 & 泠凍機・温湿調整装置 & 1792.239 & $\mathrm{~m} / \mathrm{kg}$ & 54.475 & 3.923 & 3.494 & 0.258 & 6.263 & 0.414 & 9.274 & 0.859 \\
\hline 3019011 & ポンプ及び压纕機 & 1107.272 & $\mathrm{M} / \mathrm{kg}$ & 68.070 & 2.860 & 4.613 & 0.189 & 8.914 & 0.318 & 12.777 & 0.672 \\
\hline 3019099 & 穴の他の一般産業機械 & 1183.594 & $\mathrm{M} / \mathrm{kg}$ & 51.357 & 4.382 & 3.317 & 0.289 & 5.705 & 0.454 & 9.486 & 0.937 \\
\hline 3031099 & その他の一般機械器具及び部品 & 974.620 & $\mathrm{P} / \mathrm{kg}$ & 70.252 & 2.998 & 4.528 & 0.197 & 8.738 & 0.329 & 12.626 & 0.709 \\
\hline 3211011 & 電気音㗽機器 & 4217.601 & 四 $/ \mathrm{kg}$ & 40.396 & 7.870 & 2.485 & 0.501 & 3.996 & 0.741 & 6.084 & 1.423 \\
\hline 3212099 & 他電気音㗽機器部分品 & 2613.504 & $\mathrm{M} / \mathrm{kg}$ & 51.069 & 3.852 & 3.204 & 0.246 & 4.946 & 0.372 & 7.937 & 0.740 \\
\hline 3321011 & 有線電気通信機器 & 5162.540 & $\mathrm{~B} / \mathrm{kg}$ & 44.534 & 3.733 & 2.709 & 0.242 & 4.110 & 0.389 & 6.327 & 0.802 \\
\hline 3321099 & 它の他, 霓気通信機器 & 4563.826 & $\mathrm{H} / \mathrm{kg}$ & 38.999 & 3.735 & 2.426 & 0.244 & 3.742 & 0.414 & 5.755 & 0.874 \\
\hline 3411011 & 発電機器 & 1361.265 & $\mathrm{~m} / \mathrm{kg}$ & 61.996 & 3.377 & 3.979 & 0.221 & 7.806 & 0.352 & 11.042 & 0.729 \\
\hline 3411021 & 開閉制御装置·配電盤 & 2223.304 & 由 $/ \mathrm{kg}$ & 46.012 & 4.025 & 2.930 & 0.263 & 4.902 & 0.410 & 7.753 & 0.840 \\
\hline 3411031 & Zの他の送配霓楼器 & 1194.951 & 円/kg & 62.656 & 2.449 & 4.008 & 0.160 & 7.075 & 0.270 & 10.974 & 0.569 \\
\hline 3411099 & その他の産業用重電機器 & 2386.023 & 円/ kg & 48.268 & 3.695 & 3.192 & 0.241 & 5.595 & 0.387 & 8.188 & 0.802 \\
\hline 3421011 & 電気照明器县 & 1849.811 & 巴/kg & 47.662 & 5.035 & 2.986 & 0.321 & 4.766 & 0.492 & 7.835 & 0.963 \\
\hline 3421021 & 電池 & 1899.308 & M/kg & 55.792 & 6.093 & 3.647 & 0.389 & 5.196 & 0.585 & 7.570 & 1.138 \\
\hline 3421031 & 電球 & 3098.337 & 巴/kg & 46.018 & 7.062 & 2.793 & 0.447 & 3.815 & 0.655 & 6.367 & 1.234 \\
\hline 3421041 & 配線器具 & 1975.477 & B. $\mathrm{kg}$ & 45.381 & 4.096 & 2.807 & 0.268 & 4.514 & 0.423 & 7.029 & 0.868 \\
\hline 7122011 & 道路貨物輸逵 & 35.320 & $\boxplus / \mathrm{t} \cdot \mathrm{km}$ & 79.689 & & 5.332 & & 12.523 & & 28.352 & \\
\hline $\mathrm{C} 402200$ & SRC事務所工事分倍率 & & 偣 & 0.355 & & 0.287 & & 0.207 & & 0.172 & \\
\hline $\mathrm{C} 402250$ & RC事務所工事分倍率 & & 倍 & 0.378 & & 0.301 & & 0.217 & & 0.179 & \\
\hline $\mathrm{C} 402270$ & S事務所工事分偣率 & & 经 & 0.335 & & 0.282 & & 0.188 & & 0.167 & \\
\hline
\end{tabular}


生、国土保全、土地造成は対象外とした。ただし、環境衛生のうち、 下水道事業については建設部閏分析用産業連関表のデータを用いて 分離し、下水道部門に割り付けた。固定資本マトリックスの列部門 は、108 列に統合されているため、各列部門の資本減耗引当金額に 忘じて 405 列に配分し、固定資本形成に関わる投入係数行列 S(405 $\times 405)$ を作成し、(1)式と同様にして固定資本形成に関わる境界条件 別環境負荷原単位を算出した。

\section{3 流通段階における環境角荷}

産業連関表取引基本表の需要合計欄に記載された各品目舞の各流 通産業への投入金額に、当該部門の生産者価格あたりの環境負荷原
单位を乗じて集計することにより、流通段階の環境負荷原単位を算 出した。

\section{4 製品重量あたり購入単価の分析}

基䃈資材については、産業連関表に付帯する生産額表に記載され た品目別の生産金額を生産重量で除すことによって重量あたりの生 産者価格を算出した。一方、建築設備機器などの複合製品について は、生産重量が記載されていないため、基礎資材に対して生産者洒 格あたりの重量を与え、(2)式により、究極的な資材投入量を算出し た。これを産業連関表に記載されている品目毎の生産者価格と購入 者価格の比率を利用して、製品重量あたりの購入単価を算出した。

\section{表 2 電気設備の計算条件}



\section{表 5 界降機設備工事の計算条件}

\begin{tabular}{|c|c|c|c|c|}
\hline & 费用更新 & 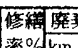 & 片道 & \\
\hline 工事科目・細目 & $\begin{array}{l}\text { 構成周斯 } \\
\text { 年 }\end{array}$ & {$\left[\begin{array}{l}\text { 事吆 } \\
/ \text { 作 }\end{array}\right.$} & 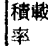 & 行 $a-k^{\circ}$ \\
\hline 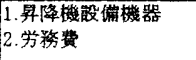 & \begin{tabular}{|l|l|}
0.3 & 25 \\
0.7 & 25 \\
\end{tabular} & \begin{tabular}{l|l|}
2 & 3 \\
2 & 3
\end{tabular} & 0.6 & \\
\hline
\end{tabular}

\section{表 3 空調設備の㖕算条件}

\begin{tabular}{|c|c|c|c|c|c|c|c|}
\hline \multicolumn{2}{|c|}{ 工事科目・細目 } & 費用 & $\begin{array}{l}\text { 更新 } \\
\text { 期期 } \\
\text { 年 }\end{array}$ & 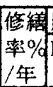 & 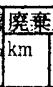 & 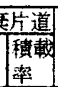 & 行 $a-k^{\circ}$ \\
\hline \multicolumn{2}{|l|}{ 1. ボイラ類 } & & & & & & \\
\hline \multicolumn{2}{|c|}{ 1.1セクショナルボ伊 } & 1 & 15 & 2 & 30 & 0.8 & 3011011 \\
\hline \multicolumn{2}{|c|}{ 1.2炉筒煙管术何 } & 1) & 15 & 2 & 30 & 0.8 & 3011011 \\
\hline \multicolumn{2}{|c|}{ 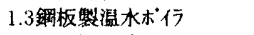 } & 1 & 15 & 2 & 30 & 0.8 & 3011011 \\
\hline \multicolumn{2}{|c|}{ 1.4Zの他の末仨 } & 1) & 15 & 2 & 30 & 0.8 & 3011011 \\
\hline \multirow{2}{*}{\multicolumn{2}{|c|}{$\begin{array}{l}\text { 2. 泠涷機 } \\
2.1 \text { 2.1 }\end{array}$}} & & & & & & \\
\hline & & 1 & 15 & 2 & 30 & 0.8 & 3013011 \\
\hline \multicolumn{2}{|l|}{ 2.2遠心式 } & 1) & 20 & 2 & 30 & 0.8 & 3013011 \\
\hline \multicolumn{2}{|l|}{ 2.3吸収式 } & 1 & 20 & 2 & 30 & 0.8 & 3013011 \\
\hline \multicolumn{2}{|l|}{2.4 ₹ 0 他式 } & i) & 20 & 2 & 30 & 0.8 & 3013011 \\
\hline \multicolumn{2}{|l|}{ 3. 汾却塔 } & 1 & 15 & 2 & 30 & 0.8 & 3013011 \\
\hline 4. 空娚機類 & & & & & & & \\
\hline 4.1 ユニット型 & & 1 & 15 & 2 & 30 & 0.6 & 3013011 \\
\hline 4.2パックー & 型 & 1 & 15 & 2 & 30 & 0.6 & 3013011 \\
\hline 4.3全㷫交換 & & 1 & 15 & 2 & 30 & 0.6 & 3011 \\
\hline 4.4ファンבイ & & 1 & 15 & 2 & 30 & 0.6 & 3011 \\
\hline 4.5放熱器 & & 1 & 15 & 2 & 30 & 0.6 & 3011 \\
\hline 4.6 Zの他(V & 等) & 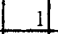 & 15 & 1 & 30 & 0.6 & 3011 \\
\hline 5.ポンブ類 & 喿台、㚏類 & 71 & 15 & 2 & 30 & 0.8 & 0011 \\
\hline 6.フフン類 (1 & 防振架台含む) & & 20 & 2 & 30 & 0.6 & 3011 \\
\hline 7. 製缶類 & & 1 & 20 & 2) & 30 & 0.8 & 2899021 \\
\hline 8. 多外類 & 銅 & 0.1 & 30 & 2 & 30 & 0.6 & 3011 \\
\hline （材工共） & 銅材 & 0.1 & 30 & 2 & 30 & 0.6 & 2812011 \\
\hline & $\not 3$ & 0.9 & 30 & & 30 & & \\
\hline 9. 配管材 & & & & & & & \\
\hline 铜管 & 直里 & 0.6 & 20 & 2 & 30 & 0.6 & 2011 \\
\hline & & 0.3 & 20 & 2 & 30 & 0.6 & 2899031 \\
\hline & & 0.1 & 20 & 2 & 30 & 0.6 & 2079021 \\
\hline & 支持金 & 0.1 & 20 & 2 & 30 & 0.6 & 1011 \\
\hline 9.2スデルス管 & 遖 & 0.4 & 20 & 2 & 30 & 0.6 & 2622012 \\
\hline & 継ぎ手 & 0.3 & 20 & 2 & 30 & 0.6 & 2899031 \\
\hline & 接合 & 0.1 & 20 & 2 & 30 & 0.6 & 2079021 \\
\hline & 支 & 0.2 & 20 & 2 & 30 & 0.6 & 2621011 \\
\hline 9.3銅管 & 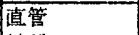 & 0.5 & 20 & 2 & 30 & 0.6 & 2722011 \\
\hline & & 0.4 & 20 & 2 & 30 & 0.6 & 2722031 \\
\hline & & 0.1 & 20 & 2 & 30 & 0.6 & 2711021 \\
\hline & 支 & 0.1 & 20 & 2 & 30 & 0.6 & 2621011 \\
\hline 9.4その他（相 & 直管 & 0.6 & 20 & 2 & 30 & 0.6 & 2211012 \\
\hline & 秤 & 0.2 & 20 & 2 & 30 & 0.6 & .012 \\
\hline & & 0.1 & 20 & 2 & 30 & 0.6 & 2079021 \\
\hline & & & 20 & l & 30 & 0.6 & 011 \\
\hline . 自動制䲗 & & & & & & & \\
\hline 動制行 & 午 & 1 & 20 & 2 & 30 & 0.6 & 3031099 \\
\hline & & 1 & 20 & 2 & 30 & 0.6 & 021 \\
\hline 㝇装工 & 電線 & 0.1 & 20 & 2 & 30 & 0.6 & 2721011 \\
\hline & ケーブ, & 0.1 & 20 & 2 & 30 & 0.6 & 2721013 \\
\hline & 配線器具 & 0 & 20 & 2 & 30 & 0.6 & 3421041 \\
\hline & 銅板艇電楾管 & 0.1 & 20 & 2 & 30 & 0.6 & 2622011 \\
\hline & 合成 & 0.1 & 20 & 2 & 30 & 0.6 & 2211012 \\
\hline & ポック & 0.1 & 20 & 2 & 30 & 0.6 & 2899021 \\
\hline & $15-$ & 0.1 & 20 & 2 & 30 & 0.6 & 2812011 \\
\hline & 妿務 & 0.5 & 20 & 2 & 30 & & \\
\hline 11. 制気口類 & & 1) & 20 & 2 & 30 & 0.6 & 1099 \\
\hline 12. 弁、計器 & 雑 & 1) & 20 & 2. & 30 & 0.6 & 3031099 \\
\hline 13. 雑材 & & 0.8 & 20 & 2 & 30 & 0.6 & 2899092 \\
\hline & & & 20 & & I & 0.6 & \\
\hline 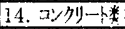 & 柱、ハント机ん & 7 & 35 & 2 & 30 & 0.6 & 2523011 \\
\hline 15. 保温、 & 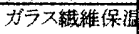 & 0.1 & 25 & 10 & 30 & 0.6 & 2512011 \\
\hline 塗装 & & 0.1 & 25 & 10 & 30 & 0.6 & 2211013 \\
\hline & 要鉛路 & 0.1 & 25 & 10 & 30 & 0.6 & 2623021 \\
\hline & ア゙ルミ板 & 0.1 & 25 & 10 & 30 & 0.6 & 2722021 \\
\hline & 㴽拄 & 0.1 & 25 & 10 & 30 & 0.6 & 2072011 \\
\hline & 劳栫 & 0.8 & 25 & 10 & & & \\
\hline 労務費 & & 1 & & & & & \\
\hline & & & & & & & 7122011 \\
\hline & & & & & & & \\
\hline その他 & & & & & & & \\
\hline
\end{tabular}

\section{表 4 衛生設備の鄉算条件}

\begin{tabular}{|c|c|c|c|c|c|c|c|}
\hline \multirow{2}{*}{\multicolumn{2}{|c|}{ 工事科 }} & \multirow{2}{*}{ 要用 } & \multicolumn{4}{|c|}{ 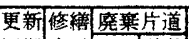 } & \multirow[b]{2}{*}{ 行 $ב-b$} \\
\hline & & & 周期 & $\mid$ & $\mathrm{km}$ & 糟較 & \\
\hline \multicolumn{2}{|l|}{ 1. 水霄類 } & & & & & & \\
\hline \multirow[t]{2}{*}{1.1 樹脂製 } & FRPパネルダ & 0.9 & 20 & 2 & 30 & 0.6 & 2211015 \\
\hline & 銅製平架台 & 0.2 & 20 & 2 & 30 & 0.6 & 2621011 \\
\hline \multirow[t]{2}{*}{1.2 その他 } & 鉄バネルタンク & 0.9 & 20 & 2 & 30 & 0.6 & 2899021 \\
\hline & 铜製平架台 & 0.1 & 20 & 2 & 30 & 0.6 & 2621011 \\
\hline \multicolumn{2}{|l|}{ 2. 製缸類 } & 1 & 20 & 2 & 30 & 0.8 & 2899021 \\
\hline \multicolumn{2}{|l|}{ 3.ポンブ類 } & & & & & & \\
\hline \multicolumn{2}{|c|}{ 3.1一般ポンプ } & 1 & 15 & 2 & 30 & 0.8 & 3019011 \\
\hline \multicolumn{2}{|c|}{ 3.2特殊ポンプ } & 1 & 15 & 2 & 30 & 0.8 & 3019011 \\
\hline \multicolumn{2}{|l|}{ 4. 林類 } & & & & & & \\
\hline \multirow{2}{*}{\multicolumn{2}{|c|}{$\begin{array}{l}4.1 \text { 給湯ボイラ } \\
4.2 \text { 湯沸器 }\end{array}$}} & 1 & 15 & 2 & 30 & 0.8 & 3011011 \\
\hline & & 1) & 10 & 2 & 30 & 0.8 & 2891011 \\
\hline 4.3 その他 & & 1 & 10 & 2 & 30) & 0.8 & 2891011 \\
\hline 5. 衛生器自 & 露生陶器 & 0.8 & 25 & 2 & 30 & 0.6 & 2531011 \\
\hline & 衛生用金具 & 0.2 & 15 & 2 & 30 & 0.6 & 2899031 \\
\hline 6. 消火检 & & 1 & 20 & 2 & 30 & 0.6 & 3031099 \\
\hline 7. 特殊消尣 & 大設槽 & & & & & & \\
\hline $7.1 \times フ^{\circ}$ リタラ & 機器 & 1 & 20 & 2 & 30 & 0.6 & 3031099 \\
\hline 7.2化学消 & 火機器 & 1) & 20 & 2 & 30 & 0.6 & 3031099 \\
\hline 8. 銓管、鍷 & 鉄管類 & & & & & & \\
\hline 8.1 鋼管 & 㨁管 & 0.6 & 20 & 2 & 30 & 0.6 & 2622011 \\
\hline & 継ぎ手 & 0.3 & 20 & 2 & 30 & 0.6 & 2899031 \\
\hline & 接合材 & 0.1 & 20 & 2 & 30 & 0.6 & 2079021 \\
\hline & 支持金物 & 0.1 & 20 & 2 & 30 & 0.6 & 2621011 \\
\hline 8.2 スデルス & 直管 & 0.4 & 20 & 2 & 30 & 0.6 & 2622012 \\
\hline 管 & 継ざ手 & 0.3 & 20 & 2 & 30 & 0.6 & 2899031 \\
\hline & 接合材 & 0.1 & 20 & 2 & 30 & 0.6 & 2079021 \\
\hline & 支持金物 & 0.2 & 20 & 2 & 30 & 0.6 & 2621011 \\
\hline 8.3鋳鉄管 & 直管 & 0.5 & 20 & 2 & 30 & 0.6 & 2631021 \\
\hline & 継ざ平 & 0.4 & 20 & 2 & 30 & 0.6 & 2631.031 \\
\hline & 支持金物 & 0.1 & 20 & 2 & 30 & 0.6 & 2621011 \\
\hline 8.4 銅管 & 直管 & 0.5 & 20 & 2 & 30 & 0.6 & 2722011 \\
\hline & 能ぎ手 & 0.4 & 20 & 2 & 30 & 0.6 & 2722031 \\
\hline & 接合材 & 0.1 & 20 & 2 & 30. & 0.6 & 2711021 \\
\hline & 支持金物 & 0.1 & 20 & 2 & 30 & 0.6 & 2621011 \\
\hline 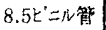 & 茞管 & 0.6 & 20 & 2 & 30 & 0.6 & 2211012 \\
\hline & 継ぎ手 & 0.2 & 20 & 2 & 30 & 0.6 & 2211012 \\
\hline & 接合材 & 0.1 & 20 & 2 & 30 & 0.6 & 2079021 \\
\hline & 支持金物 & 0.2 & 20 & 2 & 30 & 0.6 & 2621011 \\
\hline 8.6 その他 & ヒz-A管 & 1) & 20 & 2 & 30. & 0.6 & 2523011 \\
\hline 9. 弁、尌器 & 、䕌金物類 & + & 20 & 2 & 30 & 0.6 & 3031099 \\
\hline 10. 雅材 & 鎮線 & 0.8 & 20 & 2 & 30 & 0.6 & 2899092 \\
\hline & ビニル & 0.2 & 20 & 2 & 30 & 0.6 & 2211011 \\
\hline $11 . .3 \times$ 夘-1 & 基碳，拁，排水相 & 1 & 35 & 2 & 30 & 0.8 & 2523011 \\
\hline 12. 保温、 & カラス織維保温 & 0.1 & 20 & 10 & 30 & 0.6 & 2512011 \\
\hline 塗装 & ポりスチレンフ & 0.1 & 20 & $10 \mid$ & 30 & 0.6 & 2211013 \\
\hline & 亜辑鉄板 & 0.1 & 20 & 10 & 30 & 0.6 & 2623021 \\
\hline & アルミ板・箔 & 0.1 & 20 & 10 & 30 & 0.6 & 2722021 \\
\hline & 浴料 & 0.1 & 20 & 10 & 30 & 0.6 & 2072011 \\
\hline & 労務 & 0.8 & 20 & 10 & & & \\
\hline ガス工其 & 鎍管 & 0.2 & 20 & 2 & 30 & 0.6 & 2622011 \\
\hline & 継ぎ乎 & 0.1 & 20 & 2 & 30 & 0.6 & 2899031 \\
\hline & 接合材 & 0 & 20 & 2 & 30 & 0.6 & 2079021 \\
\hline & 支持金物 & 0 & 20 & 2 & 30 & 0.6 & 2621011 \\
\hline & 弁等 & 0 & 20 & 2 & 30 & 0.6 & 3031099 \\
\hline & 労愁費 & 0.7 & 20 & 2. & & & \\
\hline 14. 労狢費 & 搬入据付、根某 & 1 & & & & & \\
\hline $\begin{array}{l}\text { 15. 運搬費 } \\
\text { 16. 現場雜 }\end{array}$ & & 1 & & & & & $712: 011$ \\
\hline 17.引き込 & 䑺管 & 0.2 & 20 & 2 & 30 & 0.6 & 2622011 \\
\hline & 継ぎ手 & 0.1 & 20 & 2 & 30 & 0.6 & 2899031 \\
\hline & 接合材 & 0 & 20 & 2) & 30 & 0.6 & 2079021 \\
\hline & 弁等 & 0 & 20 & 2) & 30 & 0.6 & 3031099 \\
\hline & 労務費 & 0.7 & 20 & & 30 & & \\
\hline 8.その他 & & & 20 & it & & & \\
\hline
\end{tabular}


$\mathbf{W}=\mathbf{W}[\mathbf{I}-\mathbf{A}]^{-1}$

(2)

W: 国内生産額あたりの直接的な資材投入重量ベクトル $(1 \times 405)$

$\mathrm{w}$ : 生産者価格あたりの直接·間接資材投入重量ベクトル $(1 \times 405)$

$\mathbf{A}$ : 投入係数行列 $(405 \times 405) 、 \mathbf{A}=\mathbf{A}_{\mathbf{d}}+\mathbf{A}_{\mathbf{m}}{ }^{\prime}+\mathbf{A}_{\mathbf{m}}{ }^{*}((1)$ 式の凡例参照 $)$

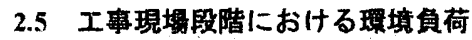

建設部門分析用産業連関表を利用して、27 細目の建物用途別・構

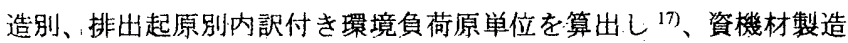
および流通段階までの環境負荷を 1 とした時の、それ以外の環境負 荷の割合を求めた。その結果を表 1 の最下欄に示す。これを利用し て工事現場段階における環境負荷を簡易的に計上することとした。

妻 6 電気設備の床面積あたり工事単価、資機材重睤、資機材製造十工事分 $\mathrm{CO}_{2}$ 排出量

\begin{tabular}{|c|c|c|c|c|c|c|c|c|c|c|c|c|c|c|c|c|c|c|}
\hline & \multicolumn{6}{|c|}{ 工事単価 $\left(\mp \mathrm{m} / \mathrm{m}^{2}\right)$} & \multicolumn{6}{|c|}{ 貿機材重量 $\left(\mathrm{kg} / \mathrm{m}^{2}\right)$} & \multicolumn{6}{|c|}{ 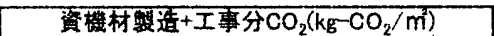 } \\
\hline & 平均 & $\begin{array}{l}1000 \mathrm{~m}^{2} \\
\text { 去满 }\end{array}$ & $\begin{array}{l}100 \mathrm{~m}^{2} \\
\text { Lt }\end{array}$ & $\begin{array}{l}3000 \mathrm{~m}^{2} \\
\text { 以上 }\end{array}$ & $\begin{array}{l}5000 \mathrm{~m}^{2} \\
k \text { L }\end{array}$ & \begin{tabular}{|l|}
10000 \\
$\mathrm{~m}^{2} \mathrm{ES}$ 上
\end{tabular} & 西均 & $\int_{\text {本满 }}^{100 \mathrm{~m}^{2}}$ & $\begin{array}{l}1000 \mathrm{~m}^{2} \\
\mathrm{k}\end{array}$ & $\begin{array}{l}3000 \mathrm{~m}^{2} \\
\mathrm{~L}\end{array}$ & $5000 \mathrm{~m}^{2}$ & $\begin{array}{l}10000 \\
\mathrm{~m}^{2} \mathrm{E} \text { 上 }\end{array}$ & 平均 & $\begin{array}{l}1000 \mathrm{~m}^{2} \\
\text { 垁满 }\end{array}$ & $\begin{array}{l}1000 \mathrm{~m}^{2} \\
\text { LL }\end{array}$ & $\begin{array}{l}3000 \mathrm{~m}^{2} \\
\mathrm{KL}\end{array}$ & $\begin{array}{l}5000 \mathrm{~m}^{2} \\
\text { wh }\end{array}$ & $\begin{array}{l}10000 \\
m^{2} B L L\end{array}$ \\
\hline 1. 変電設備 & 3.82 & 2.38 & 2.74 & 2.46 & 2.76 & 5.56 & 2.52 & $\frac{1.57}{1.57}$ & 1.81 & 1.62 & 1.82 & 3.67 & 14.58 & 9.08 & 10.46 & 9.39 & 10.53 & 21.22 \\
\hline 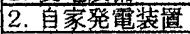 & 0.40 & 0.00 & 0.03 & 0.30 & 0.80 & 3.40 & 0.34 & 0.00 & 0.02 & 0.26 & 0.69 & 2.91 & 1.74 & 0.00 & 0.12 & 1.31 & 3.49 & 14.83 \\
\hline 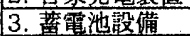 & 0.09 & 0.00 & 0.00 & 0.03 & 0.27 & 0.96 & 0.05 & 0.00 & 0.00 & 0.02 & 0.15 & 0.52 & 0.38 & 0.00 & 0.00 & 0.13 & 1.12 & 3.99 \\
\hline 4. 量類 & 3.62 & 2.48 & 2.12 & 2.94 & 3.42 & 5.42 & 1.68 & 1.15 & 0.98 & 1.36 & 1.59 & 2.51 & 11.91 & 8.16 & 6.97 & 9.67 & 11.25 & 17.82 \\
\hline 5. 弱䇩機器 & 1.36 & 0.87 & 0.70 & 1.48 & 0.96 & 3.41 & 0.28 & 0.17 & 0.14 & 0.31 & 0.19 & 0.73 & 4.14 & 2.64 & 2.13 & 4.51 & 2.92 & 10.40 \\
\hline 6.6 防後機器 & 0.80 & 0.47 & 0.56 & 0.47 & 0.76 & 1.29 & 0.24 & 0.16 & 0.15 & 0.15 & 0.21 & 0.42 & 2.35 & 1.44 & & 1.41 & 2.19 & 3.92 \\
\hline 7. 照明器真 & 4.91 & 3.51 & 3.11 & 3.25 & 3.65 & 5.37 & 2.68 & 1.91 & .70 & 1.77 & 1.99 & 2.94 & 16.71 & 11.94 & 10.58 & 11.06 & 12.42 & 18.27 \\
\hline 8. 配線材 & 1.18 & 0.80 & 0.92 & 0.88 & 0.99 & 1.92 & 0.73 & 0.48 & 0.56 & 0.54 & 0.62 & 1.24 & 5.27 & 3.59 & 4.12 & 3.90 & 4.39 & 8.65 \\
\hline 9.配管材 & 1.53 & 1.12 & 1.20 & 1.29 & 1.08 & 1.24 & 5.23 & -4.00 & 4.07 & 4.26 & 3.66 & 3.99 & 11.55 & 8.61 & 9.03 & 9.60 & 8.13 & 9.15 \\
\hline 10. 配線器具 & 0.55 & $0: 40$ & 0.38 & 0.57 & 0.43 & 0.54 & 0.29 & 0.21 & 0.20 & 0.30 & 0.22 & 0.28 & 1.74 & 1.27 & 1.20 & 1.81 & 1.36 & 1.71 \\
\hline 11. 雜材 & 1.51 & 1.19 & 1.06 & 1.01 & 1.17 & 1.29 & 2.36 & 1.87 & 1.67 & 1.58 & 1.84 & 2.02 & 8.17 & 6.44 & 5.73 & 5.47 & 6.33 & 6.98 \\
\hline 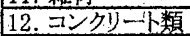 & 0.30 & 0.40 & 0.23 & 0.12 & 0.08 & 0.17 & 12.91 & 17.22 & 9.90 & 5.17 & 3.44 & 7.32 & 2.53 & 3.37 & 1.94 & 1.01 & 0.68 & 1.43 \\
\hline 1.3.浴装 & 0.13 & 0.15 & 0.06 & 0.12 & 0.13 & 0.16 & 0.02 & 0.02 & 0.00 & 0.02 & 0.02 & 0.02 & 0.06 & 0.06 & 0.00 & 0.06 & 0.06 & 0.06 \\
\hline 14, 労雅費 & 7.72 & 5.49 & 5.28 & 6.28 & 5.28 & 7.68 & 0.00 & 0.00 & 0.00 & 0.00 & 0.00 & 0.00 & 0.00 & 0.00 & 0.00 & 0.00 & 0.00 & 0.00 \\
\hline 15. 運搬費 & 0.51 & 0.33 & 0.47 & 0.26 & 0.23 & 0.38 & 0.00 & 0.00 & 0.00 & 0.00 & 0.00 & 0.00 & 2.80 & $1.81^{\prime}$ & 2.58 & 1.43 & 1.26 & 2.09 \\
\hline 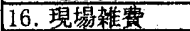 & 1.93 & 1.01 & 1.19 & 1.96 & 1.79 & 2.99 & 0.00 & 0.00 & 0.00 & 0.00 & 0.00 & 0.00 & 0.00 & 0.00 & 0.00 & 0.00 & 0.00 & 0.00 \\
\hline$\frac{17 . \text { その他 }}{17}$ & 0.15 & 0.00 & 0.09 & 0.22 & 0.00 & 0.88 & 0.15 & 0.00 & 0.10 & 0.16 & 0.00 & 0.60 & 0.42 & 0.00 & 0.25 & 0.57 & 0.00 & 2.54 \\
\hline 18. 共通兾分 & 8.99 & 7.61 & 6.76 & 7.16 & 6.71 & 10.39 & 0.00 & 0.00 & 0.00 & 0.00 & 0.00 & 0.00 & 25.39 & 17.58 & 17.08 & 18.45 & 19.90 & 37.04 \\
\hline 合 & $39: 50$ & 28.21 & 26.90 & 30.80 & 30.51 & 53.05 & 29.48 & 28.76 & 21.30 & 17.52 & 16.44 & 29.17 & 09.74 & 75.99 & 73.80 & 79.78 & 86.03 & 60.10 \\
\hline
\end{tabular}

表 7 空調設備の休面積あたり工事単価、資機材董量、資機材製造+工事分 $\mathrm{CO}_{2}$ 排出量

\begin{tabular}{|c|c|c|c|c|c|c|c|c|c|c|c|c|c|c|c|c|c|c|}
\hline & \multicolumn{6}{|c|}{ 工事單洒 $\left(千 \mathrm{q} / \mathrm{m}^{2}\right)$} & \multicolumn{6}{|c|}{ 盗機材重㻎 $\left(\mathrm{kg} / \mathrm{m}^{2}\right)$} & \multicolumn{6}{|c|}{ 贔譏材製造 + 工事分 $\mathrm{CO}_{2}\left(\mathrm{~kg}-\mathrm{CO}_{2} / \mathrm{m}^{2}\right)$} \\
\hline & 平均 & $\begin{array}{l}1000 \mathrm{~m}^{2} \\
\text { 丰满 }\end{array}$ & ${ }_{1000 \mathrm{~m}^{2}}$ & $3000 \mathrm{~m}^{2}$ & $5000 \mathrm{~m}^{2}$ & $\begin{array}{l}10000 \\
m^{2} \mathrm{M} \text { 上 }\end{array}$ & 平均 & 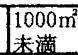 & $1000 \mathrm{~m}$ & $\begin{array}{l}3000 \mathrm{~m}^{2} \\
\mathrm{~L} \mathrm{t}\end{array}$ & $\begin{array}{l}5000 \mathrm{~m}^{2} \\
\mathrm{kt}\end{array}$ & $\begin{array}{c}10000 \\
m^{2} \mathscr{L}\end{array}$ & 平均 & 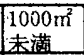 & \begin{tabular}{|l|}
$1000 \mathrm{~m}^{2}$ \\
L上
\end{tabular} & $\begin{array}{l}3000 \mathrm{~m}^{2} \\
\mathrm{EL}\end{array}$ & $\begin{array}{l}5000 \mathrm{~m}^{2} \\
\mathrm{EL}\end{array}$ & $\begin{array}{l}10000 \\
m^{2} E L\end{array}$ \\
\hline 䂞人類 & 0.03 & 0.00 & 0.00 & 0.06 & 0.05 & 0.22 & 0.03 & 0.00 & 0.00 & 0.06 & 0.05 & 0.21 & 0.12 & 0.00 & 0.00 & 0.24 & 0.20 & 0.89 \\
\hline 海涷轧 & 0.37 & 0.00 & 0.10 & .0 .83 & 0.43 & 1.75 & 0.21 & 0.00 & 0.06 & 0.48 & 0.25 & 1.01 & 1.43 & 0.00 & 0.39 & 3.21 & 1.66 & 6.76 \\
\hline 3. 冷却塔 & 0.08 & 0.00 & 0.00 & 0.16 & 0.19 & 0.43 & 0.05 & 0.00 & 0.00 & 0.09 & 0.11 & 0.25 & 0.31 & 0.00 & 0.00 & 0.62 & 0.73 & 1.66 \\
\hline 4. 空調梂類 & 13.35 & 7.26 & 7.65 & 10.08 & 10.63 & 9.72 & 7.67 & 4.17 & 4.40 & 5.79 & 6.11 & 5.59 & 51.59 & 28.06 & 29.56 & 38.96 & 41.08 & 37.56 \\
\hline 5. ホンプ類 & 0.06 & 0.00 & 0.02 & 0.12 & 0.05 & 0.38 & 0.06 & 0.00 & 0.02 & 0.11 & 0.05 & 0.35 & 0.30 & 0.00 & 0.10 & 0.59 & $\begin{array}{ll} & 0.25 \\
\end{array}$ & \\
\hline 6.ファン類 & 1.54 & 0.94 & 1.14 & 0.81 & 0.59 & 0.68 & 0.89 & 0.54 & 0.66 & 0.47 & 0.34 & 0.39 & 5.95 & 3.63 & 4.41 & 3.13 & 2.28 & 2.63 \\
\hline 7. 製缶類 & 0.10 & 0.01 & 0.04 & 0.18 & 0.17 & 0.31 & 0.17 & 0.02 & 0.07 & 0.31 & 0.30 & 0.54 & 0.58 & 0.06 & 0.23 & 1.04 & 0.98 & 1.79 \\
\hline $8 . \not$ 外類 & 3.45 & 1.09 & 2.07 & 4.01 & 4.37 & 6.21 & 3.31 & 1.04 & 1.98 & 3.79 & 4.17 & 5.87 & 5.80 & 1.80 & 3.47 & 6.66 & 7.32 & 10.32 \\
\hline 9. 配管材 & 1.28 & 0.68 & 0.81 & 0.87 & 0.91 & 1.64 & 4.74 & 2.17 & 2.56 & 3.80 & 3.69 & 9.30 & 11.03 & 5.65 & 6.66 & 7.90 & 8.06 & 16.25 \\
\hline 10.自動制验 & 1.70 & 0.30 & 0.81 & 1.57 & 2.37 & 6.05 & 1.89 & 0.33 & 0.92 & 1.64 & 2.51 & 5.94 & 5.97 & 0.91 & 2.81 & 5.55 & 8.37 & 22.08 \\
\hline 1. 制氮口類 & 1.36 & 0.74 & 0.75 & 1.18 & 1.77 & 1.02 & 1.44 & 0.78 & 0.79 & 1.25 & 1.87 & 1.08 & 6.62 & 3.60 & 3.65 & 5.74 & 8.61 & 4.96 \\
\hline 12. 老，計器，雜金物悉 & 0.55 & 0.17 & 0.24 & 0.71 & 0.49 & 1.93 & 0.58 & 0.18 & 0.25 & 0.75 & 0.52 & 2.04 & 2.68 & 0.83 & 1.17 & 3.46 & 2.39 & 9.39 \\
\hline$\frac{13 .}{13.4}$ & 0.37 & $\frac{0.21}{0.21}$ & 0.25 & 0.21 & 0.23 & 0.26 & 0.55 & 0.31 & 0.37 & 0.31 & 0.34 & 0.39 & 1.86 & 1.06 & 1.26 & 1.06 & 1.16 & 1.31 \\
\hline 14.コンクリート類 & 0.19 & 0.10 & 0.08 & 0.03 & 0.04 & 1.26 & 8.18 & 4.30 & 3.44 & 1.29 & 1.72 & 54.23 & 1.60 & 0.84 & 0.68 & 0.25 & 0.34 & 0.63 \\
\hline 15. 保温、洨装 & $\frac{0.13}{1.96}$ & $\frac{.10}{1.26}$ & 0.98 & 1.82 & $\frac{.07}{1.85}$ & $\frac{1.20}{2.80}$ & $\frac{0.10}{1.69}$ & $\frac{.001}{1.01}$ & $\frac{.47}{0.85}$ & $\frac{1.45}{1.52}$ & 1.52 & 2.37 & 4.14 & 2.49 & $\frac{2.07}{2.07}$ & 3.73 & 3.73 & 5.80 \\
\hline 16. 労橉費. & 4.91 & 3.13 & 2.87 & 3.94 & 3.84 & 5.39 & 0.00 & 0.00 & 0.00 & 0.00 & 0.00 & 0.00 & 0.00 & 0.00 & 0.00 & 0.00 & 0.00 & 0.00 \\
\hline 17. 道搬費 & 0.37 & 0.24 & 0.24 & 0.19 & 0.24 & 0.24 & 0.00 & 0.00 & 0.00 & 0.00 & 0.0 & 0.00 & 2.0 & 1. & 1.32 & 1. & 1.32 & \\
\hline 18. 現場雔费 & 1.86 & 0.75 & 1.06 & 2.35 & 1.92 & 2.48 & 0.00 & 0.00 & 0.00 & 0.00 & 0.00 & 0.00 & 0.00 & 0.0 & 0.00 & 0.00 & 0.00 & 0.00 \\
\hline $19 . \xi \sigma$ 他 & 0.06 & 0.00 & 0.00 & 0.09 & 0.00 & 0.75 & 0.06 & 0.00 & 0.00 & 0.07 & 0.00 & 1.57 & 0.18 & 0.00 & 0.00 & 0.26 & 0.00 & 2.37 \\
\hline 20. 共通费分 & 9.23 & 5.78 & 5.95 & 8.13 & 7.89 & 10.24 & 0.00 & 0.00 & 0.00 & 0.00 & 0.00 & 0.00 & 30.76 & 15.12 & 17.39 & 25.11 & 26.64 & 41.42 \\
\hline 拿 棓 & 42.82 & 22.66 & 25.06 & 37.34 & 38.03 & 53.76 & 31.52 & 14.85 & 16.37 & 21.73 & 23.55 & 91.13 & 32.95 & 65.37 & 75.17 & 08.55 & 15.12 & 79.02 \\
\hline
\end{tabular}

表 8. 衛生設備の床面糟あたり工事単洒、資機材重量、資機材製造十工事分 $\mathrm{CO}_{2}$ 排出量

\begin{tabular}{|c|c|c|c|c|c|c|c|c|c|c|c|c|c|c|c|c|c|c|}
\hline & \multicolumn{6}{|c|}{ 工事唓価 $\left(千 \mathrm{f} / \mathrm{m}^{2}\right)$} & \multicolumn{6}{|c|}{ 凟磼材重量 $\left(\mathrm{kg} / \mathrm{m}^{2}\right)$} & \multicolumn{6}{|c|}{ 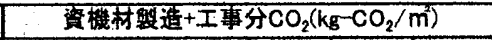 } \\
\hline & 平均 & $\begin{array}{l}1000 \mathrm{~m}^{2} \\
\text { 未满 }\end{array}$ & $\begin{array}{l}1000 \mathrm{~m}^{2} \\
\mathrm{LL}\end{array}$ & $\begin{array}{l}3000 \mathrm{~m}^{2} \\
\mathrm{EL} L\end{array}$ & $\mid \begin{array}{l}5000 \mathrm{~m}^{2} \\
\text { 以上 }\end{array}$ & $\begin{array}{l}10000 \\
m^{2} L^{2} 25\end{array}$ & 片均 & $\begin{array}{l}1000 \mathrm{~m}^{2} \\
1 \text { 满 }\end{array}$ & $\begin{array}{l}1000 \mathrm{~m}^{2} \\
\mathrm{z}\end{array}$ & $3000 \mathrm{~m}^{2}$ & $\begin{array}{l}5000 \mathrm{~m}^{2} \\
1 \mathrm{~L}\end{array}$ & $\begin{array}{l}10000 \\
m^{2} 以 上 5\end{array}$ & 平均 & $\begin{array}{l}1000 \mathrm{~m}^{2} \\
\text { 来满 }\end{array}$ & $1000 \mathrm{~m}^{2}$ & $3000 \mathrm{~m}^{2}$ & $5000 \mathrm{~m}^{2}$ & {$\left[\begin{array}{l}10000 \\
m^{2} \text { 以上 }\end{array}\right.$} \\
\hline 永槽類 & 0.80 & 0.56 & 0.62 & 0.90 & 0.65 & 0.67 & 2.44 & $\frac{1.71}{1.11}$ & 1.90 & 2.75 & 1.98 & & 5.77 & $\frac{4.04}{4.04}-10$ & $\frac{1.49}{4.49}$ & 6.49 & 4.69 & 4.85 \\
\hline 慗学類 & 0.03 & 0.00 & 0.02 & 0.05 & 0.08 & 0.04 & 0.05 & 0.00 & 0.04 & 0.09 & 0.14 & 0.07 & 0.17 & 0.00 & 0.12 & 0.29 & 0.46 & 0.23 \\
\hline 米ンフ類 & 0.70 & 0.81 & 0.50 & 0.64 & 0.62 & 0.68 & 0.65 & 0.75 & 0.47 & 0.60 & 0.58 & 0.63 & 3.46 & 4.01 & 2.47 & 3.17 & 3.07 & 3.36 \\
\hline 4. 木 & 0.52 & 0.59 & 0.47 & 0.37 & 0.54 & $\overline{0.4 !}$ & 0.88 & 1.00 & 0.80 & 0.64 & 0.90 & 0.8 & 2.5 & & & 1.82 & & \\
\hline 5. 衛生器具 & 1.37 & 1.21 & 1.19 & 1.02 & 1.23 & 0.68 & 4.57 & 4.04 & 3.97 & 3.40 & 4.10 & 2.27 & 5.85 & 5.17 & 5.08 & 4.36 & 5.25 & 2.90 \\
\hline 消炎栓 & 0.27 & 0.09 & 0.21 & 0.32 & 0.57 & 0.28 & 0.29 & 0.10 & 0.2 & 0.34 & 0.60 & 0.30 & 1.31 & 0.44 & 1.02 & 1.56 & 2.77 & 1.36 \\
\hline 7. 特殊消炎 & 0.41 & 0.00 & 0.14 & 0.52 & 0.91 & 2.34 & 0.43 & 0.00 & 0.1 & 0.55 & 0.96 & 2.47 & 2.00 & 0.00 & 0.6 & 2.53 & 4.43 & 11.39 \\
\hline 8.龬管，鉱鉄管類 & 1.63 & 1.79 & 1.36 & 1.43 & 1.57 & 1.78 & 13.34 & $15: 35$ & 10.60 & 10.50 & 12.88 & 19.92 & 15.98 & 16.62 & 13.13 & 14.96 & 16.38 & 17.78 \\
\hline 9、弁、訫器、雑金物類 & 0.68 & 0.75 & 0.58 & 0.50 & 0.57 & 0.64 & 0.72 & 0.79 & 0.61 & 0.53 & 0.60 & 0.68 & 3.31 & 3.65 & 2.82 & 2.43 & 2.77 & 3.12 \\
\hline 10. 雑材 & 0.25 & 0.16 & 0.28 & 0.12 & 0.16 & $0: 27$ & 0.37 & 0.24 & 0.42 & 0.18 & 0.24 & 0.40 & 1.26 & 0.8 & 1.41 & 0.61 & 0.81 & 1.36 \\
\hline 11.コンクリート類 & 0.52 & 0.99 & 0.37 & 0.26 & 0.38 & 0.29 & 22.38 & 42.61 & 15.93 & 11.19 & 16.36 & 12.48 & 4.39 & 8.35 & 3.12 & 2.19 & 3.21 & 2.45 \\
\hline 12. 保温;潦装 & 0.69 & 0.57 & 0.57 & 0.61 & 0.86 & 0.88 & 0.59 & 0.49 & 0.49 & 0.52 & 0.73 & 0.74 & 1.45 & 1.20 & 1.20 & 1.29 & 1.78 & 1.82 \\
\hline 13.カJス工事 & 0.57 & 0.56 & 0.47 & 0.57 & 0.77 & 0.55 & 1.26 & 1.24 & 1.04 & 1.26 & 1.71 & 1.23 & 1.96 & 1.93 & 1.62 & 1.96 & 2.65 & 1.90 \\
\hline 14. 学務費 & 3.48 & 3.40 & 2.54 & 3.03 & 3.5 & 4.25 & 0.00 & 0.00 & 0.00 & 0.00 & 0.00 & 0.00 & 0.00 & 0.00 & 0.00 & 0.0 & 0 & \\
\hline 15. 運搬賈 & 0.19 & 0.21 & 0.14 & 0.13 & 0.19 & 0.25 & 0.00 & 0.00 & 0.00 & 0.00 & 0.00 & 0.0 & 1.0 & & 0.7 & 0. & 04 & 1.37 \\
\hline 16. 現場雑䨋 & 0.74 & 0.62 & 0.47 & & 0.86 & 1.09 & 0.00 & 0.00 & 0.00 & 0.00 & 0.00 & 0.00 & 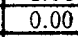 & 0.0 & 0.00 & 0.1 & 0.00 & 0.00 \\
\hline 17. Jॉ人 & 0.81 & 1.45 & 0.57 & 0.3 & 0.51 & 0.15 & 1.60 & 2.86 & 1.12 & 0.61 & 1.01 & 0.3 & 2.5 & 4. & & 0.99 & 1. & 0.4 \\
\hline $18 . z 0$ & 0.09 & 0.00 & 0.01 & 0.02 & 0.00 & 0.98 & 0.33 & 0.00 & 0. & 0.06 & 0.0 & 2.8 & 0.35 & 0.00 & 0.04 & 0.08 & 0.00 & 3.63 \\
\hline 19. 共通要分 & & 4.84 & 3.47 & 3.5 & 3.92 & 4.1 & 0.00 & 0.00 & 0.00 & 0.00 & 0.00 & 0.00 & 16.0 & 16.52 & 12.67 & 13.67 & 16.12 & 18.17 \\
\hline 合 & & & & & & 1.1 & 99.90 & & 37.80 & & 22.7 & .18 & 9.50 & 1.40 & 54.7 & $59: 11$ & 69.68 & 8.53 \\
\hline
\end{tabular}




\section{6 建策設備の新築時における環境鱼荷}

工事原価分析情報 ${ }^{233}$ に記載されている 1995 年中に拨工した 111 件の事務所ビル規模別電気・空調・衛生・算降機の各設備工事細目 金額に基づき、建築工事標準部挂等 25,26)を用いて、産業連関表の部 門分類に合うように組々目の割合を定め、表 $2 \sim 5$ に示すように産業 連関表の行部門に割り付けた。さらに、同統計資料に記載されてい る工期データに基づき着工年を算出し、設備資機材等単価指数表 ${ }^{24)}$ を利用して 1990 年価格に補正した。これに表 1 に示す初期データを 乗ずることにより、初期建設時の環境負荷を算出した。

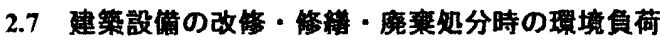

表 2〜5に示すように、各種設備機器及び瓷枋の更新周期 (年) お よび修繬率（\%/年）をライフサイクルコスト分析手法に関する文献 21),22)上り設定した。また、改修工事・修䌉・廃㶳処分時に撤去され る設備機器・凟材・廃材の片道輸送距離を $30 \mathrm{~km}$ とし、車両積載率 （最大積載重量に対する実際の積載重量の比率）を、容積が大きい 割に重量が少ないものが 0.6、重量が多いものが 0.8 と設定した。

評価対象期間を 100 年とし、建替周期を 35 年、50 年、100 年等を 設定して、新筑工事、建替工事、修繥、改修工事、廃裹処分每の環 境負荷原単位を算出した。なお、廃棄処分については、修絴時、更 新時、解体時に発生する廃材重量を基に、搬送分のみを計上し、廃 材処理(再生、焼却、埋立等)については今回検討対象外とした。

\section{3. 㻴境負荷原単位の算出結果と考察}

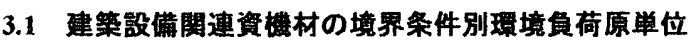

2.1〜2.5 に示す方法で算出した建築設備関連資機材の境界条件別 の $\mathrm{CO}_{2} 、 \mathrm{SO} \mathrm{x} 、 \mathrm{NO} \mathrm{x} 、$ 、ネルギー原単位、各種資機材重量あたり の購入単価を表 1 に示す。誌面の制約上、 $\mathrm{CO}_{2} 、 \mathrm{SO} \times$ について、国 内分／海外分、消費支出分／固定資本形成分、生産段階分／流通段 階分の内訳を示した。

\section{2 建筑設備の新築時における環境負荷原単位}

電気設備の床面皘あたりの工事単価（1990 年価格、消費税別）、 資機材重量、 $\mathrm{CO}_{2}$ 排出量の工事細目内訳を表 6 亿示す。床面積が大 きくなるに連れて、床面積あたりの工事単価（千円 $/ \mathrm{m}^{2} ） 、$ 資機材重 量 $\left(\mathrm{kg} / \mathrm{m}^{2}\right) 、 \mathrm{CO}_{2}$ 排出量 $\left(\mathrm{kg}-\mathrm{CO}_{2} / \mathrm{m}^{2}\right)$ が大きくなっている。これは、 大規模になるほど、受変電設備、防㷋設備、弱電設備などの設備内 容が高級になっていることを反映しているものと考えられる。

空調設備を表 7 に、衛生設備を表 8 に示す。電気設備と同様の傾 向が読み取れる。なお、電気設備、衛生設備については、1000 m未 渵の原単位が大きくなっているが、これは、規模が小さくても装備 しなければならない設備内容が空調設備に比べて多く、スケールデ メリットが生じたためと考えられる。

\section{3 建策設備のライフサイクル環境負荷原単位}

電気、空調、衛生、昇降機設備の新勧、建替、修絽、改修、廃棄 に関方る $\mathrm{LCCO}_{2}$ を表 9 に示す。左側の建替周期 35 年の建替工事欄 には、評価対象期閒 100 年間に 2 回行われる建替えに伴う電気設備 工事が計上されている。建替周期が 35 年、50 年、100 年と長くなる に従って、建替の道連れで発生する設備工事は减少するが、設備細 目毎に設定した更新周期に応じて発生する改修工事は増大している。 建替周期と設備細目每の更新周期の微妙なバランスが計算結果に影 響しているものの、総合計としては極端な違いは見られない。

同様にして、LCSOx、LCNO x、LCE、LCC のデータを表 10〜 13 に示す。

\section{4. まとめ}

建築物は、多種多様な製品とサービスによって建設・運用される 一品生産品である。このため、大量生産される他の工業製品のよう に、詳細なライフサイクルアセスメント（LCA）を実施することは、 時間的にも経済的にも困難であり、設計初期段階にも使える実用的 なLCA手法とデータベースが求められてきた。

表 9 事務所ビルの電気・機械設備の床面樌あたり年平均 $\mathrm{LCCO}_{2}\left(\mathrm{~kg}-\mathrm{CO}_{2} /\right.$ 年 $\left.\mathrm{m}^{2}\right)$

\begin{tabular}{|c|c|c|c|c|c|c|c|c|c|c|c|c|c|c|c|c|c|c|}
\hline & \multicolumn{6}{|c|}{ 建替圈期35年 } & \multicolumn{6}{|c|}{ 建替周期50年 } & \multicolumn{6}{|c|}{ 建替周期 100 年 } \\
\hline & 均 & \begin{tabular}{|l|}
$1000 \mathrm{~m}^{2}$ \\
来淽
\end{tabular} & $\begin{array}{l}1000 \mathrm{~m}^{2} \\
20 \text { L }\end{array}$ & $\begin{array}{l}3000 \mathrm{~m}^{2} \\
2 \mathrm{~L}\end{array}$ & $\begin{array}{l}5000 \mathrm{~m}^{2} \\
\underline{1} \text { 上 }\end{array}$ & $\begin{array}{l}10000 \\
\mathrm{~m}^{2} \mathscr{L} \text { 上 }\end{array}$ & 平均 & $\begin{array}{l}1000 \mathrm{~m}^{2} \\
\text { 类满 }\end{array}$ & $\begin{array}{l}1000 \mathrm{~m}^{2} \\
15 \pm\end{array}$ & $\begin{array}{l}3000 \mathrm{~m}^{2} \\
125\end{array}$ & $\begin{array}{l}5000 \mathrm{~m}^{2} \\
215\end{array}$ & $\begin{array}{l}10000 \\
m^{2} \mathrm{~L}\end{array}$ & 均 & $\begin{array}{l}1000 \mathrm{~m}^{2} \\
\text { 来满 }\end{array}$ & $\begin{array}{l}1000 \mathrm{~m}^{2} \\
5 \mathrm{~L}\end{array}$ & $\begin{array}{l}3000 \mathrm{~m}^{2} \\
20 \mathrm{~L}\end{array}$ & $\begin{array}{l}5000 \mathrm{~m}^{2} \\
5 L\end{array}$ & $\begin{array}{l}0000 \\
n^{2} N L\end{array}$ \\
\hline 霜工事 & 1.10 & \begin{tabular}{|c|}
0.76 \\
\end{tabular} & 0.74 & 0.80 & 0.86 & 1.60 & 1.10 & 0.76 & 0.74 & 0.80 & 0.86 & 1.60 & 1.10 & 0.76 & 0.74 & 0.80 & 0.86 & 1.60 \\
\hline 電建替工事 & 2.19 & 1.52 & 1.48 & 1.60 & 1.72 & 3.20 & 1.10 & 0.76 & 0.74 & 0.80 & 0.86 & 1.60 & 0.00 & 0.00 & 0.00 & 0.00 & 0.00 & 0.00 \\
\hline 気庭縡 & 1.98 & 1.35 & 1.28 & 1.40 & 1.57 & 3.08 & 1.98 & 1.35 & 1.28 & 1.40 & 1.57 & 3.08 & 1.98 & 35 & 1.28 & 1.40 & 1.57 & 30 \\
\hline 設医焂工事 & 0.99 & 0.65 & 0.59 & 0.69 & 0.86 & 1.85 & 2.87 & 1.95 & 1.87 & 2.06 & 2.33 & 4.56 & 3.80 & 2.60 & 2.51 & 2.77 & 3.05 & 5.92 \\
\hline 備庭裹処分 & 0.02 & 0.01 & 0.01 & 0.01 & 0.01 & 0.02 & 0.02 & 0.02 & 0.0 & 0.01 & 0.0 & 0.0 & 0.02 & & & & 0.01 & \\
\hline 合 圾 & 6.28 & 4.29 & 4.10 & 4.50 & 5.02 & 9.75 & 7.07 & 4.84 & 4.64 & 5.07 & 5.63 & 10.86 & 6.90 & 4.73 & 4.54 & 4.98 & 5.49 & 0.6 \\
\hline 新筑工事 & 1.33 & 0.65 & 0.75 & 1.09 & 1.15 & 1.79 & 1.33 & 0.65 & 0.75 & 1.09 & 1.15 & 1.79 & 1.33 & 0.65 & 0.75 & 1.09 & 1.15 & \\
\hline 空犍替工事 & 2.66 & 1.31 & 1.50 & 2.17 & 2.30 & 3.58 & 1.33 & 0.65 & 0.75 & 1.09 & 1.15 & 1.79 & 0.00 & 0.00 & 0.00 & 0.00 & 0.00 & 0.0 \\
\hline 調修綐 & 3.04 & 1.53 & 1.68 & 2.53 & 2.66 & 4.16 & 3.04 & 1.53 & 1.68 & 2.53 & 2.66 & 4.16 & 3.04 & 1.53 & 1.68 & 2.53 & 2.66 & 4.16 \\
\hline 設藪修工事 & 3.46 & 1.71 & 1.96 & 2.80 & 2.96 & 4.26 & 4.87 & 2.39 & 2.76 & 4.00 & 4.23 & & 6.33 & & 358 & 5.13 & 5.39 & \\
\hline 備魔粪処分 & 0.03 & 0.01 & 0.01 & 0.02 & 0.02 & 0.07 & 0.03 & 0.01 & 0.01 & 0.02 & 0.02 & 0.06 & 0.03 & 0.0 & 0.01 & 0.02 & 0.02 & 0.0 \\
\hline & 10.52 & 5.21 & 5.90 & 8.61 & 9.09 & 13.86 & 10.60 & 5.23 & 5.95 & 8.73 & 9.21 & 13.90 & 10.73 & 5.37 & 6.02 & 8.77 & 9.22 & 3.59 \\
\hline 事 & 0.69 & 0.71 & 0.55 & 0.59 & 0.70 & 0.79 & 0.69 & 0.71 & 0.55 & 0.59 & 0.70 & 0.79 & 0.69 & 0. & 0.55 & 0.59 & 0.70 & 0.79 \\
\hline 衛建替工事 & 1.39 & 43 & & & & 1.57 & 0.69 & 0.71 & 0.55 & 0.59 & 0.70 & & 0.00 & 0. & 0.00 & 0.00 & 0.00 & 0.00 \\
\hline 庭 & 1.52 & 1.52 & 1.21 & 1.1 & 1.5 & 1.73 & 1.52 & 1. & 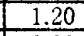 & 1.30 & 1.55 & 1.7 & 1.52 & 1.5 & 1.2 & 1.30 & 1.55 & 1.73 \\
\hline 設臨修工事 & 1.86 & 1.80 & 1.4. & 1. & 1.93 & 2.2 & 2. & 2.40 & 2. & 2.22 & 2.59 & 2.9 & 2.8 & 2.8 & 2.26 & 2.45 & 2.87 & 3.2 \\
\hline 俑廃裹処分 & 0.04 & 0.05 & 0. & 0.0 & & 0.04 & 0.03 & & & & & & & 0. & 0.0 & $\pi$ & 13 & 0.04 \\
\hline & 5.50 & 51 & 4.37 & 4.7 & 5.60 & 6.38 & 5.4 & & 4.33 & 4.7 & 5. & 6. & 5.0 & & 4. & & & \\
\hline 工事 & 0.36 & & & 0.5 & 0.3 & 0.27 & $\overline{0.3}$ & 0. & & 0.5 & $\overline{0.3}$ & & & & & & & 0.2 \\
\hline 昇崖替工事 & 0.72 & 0.77 & 0. & 1.04 & 0.6 & 0.5 & 0.3 & 0.39 & 0. & 0. & 0. & 0. & 0.00 & 0.0 & 0.00 & 0.00 & 0.00 & 0.00 \\
\hline 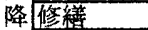 & & 0.77 & & 1.8 & & 0 . & & & & 10 & & & & 0. & & & 0.69 & \\
\hline 改隻工事 & 0.00 & 0.00 & 0.00 & 0.00 & 0.00 & 0.00 & 0.72 & 0.77 & 0.4 & 1.04 & 0.6 & & 1.07 & 1.16 & 0.61 & 6 & 44 & 0.8 \\
\hline 廃蒹処分 & 0.00 & 0.00 & 0.00 & 0.01 & 0.00 & 0.00 & 0.00 & 0.01 & 0.00 & 0.01 & 0.00 & 0.00 & 0.00 & 0.01 & 0.00 & 0.01 & 0.00 & 0.00 \\
\hline III & 1.80 & 1.93 & 1.02 & 26 & 1.73 & 1.37 & 2.16 & 2.33 & 102 & 3.1 & 2.08 & 1.64 & 2.15 & 2.33 & 1.22 & 3.13 & 2.08 & 1.6 \\
\hline
\end{tabular}


表 10 事務所ビルの電気・機械設備の床面皘あたり年平均 $\mathrm{LCSOx}\left(\mathrm{g}-\mathrm{SO}_{2} /\right.$ 年 $\left.\mathrm{m}^{2}\right)$

\begin{tabular}{|c|c|c|c|c|c|c|c|c|c|c|c|c|c|c|c|c|c|c|}
\hline & \multicolumn{6}{|c|}{ 建替周期35年 } & \multicolumn{6}{|c|}{ 建替周期50年 } & \multicolumn{6}{|c|}{ 建智周期100年 } \\
\hline & 平均 & $\begin{array}{l}1000 \mathrm{~m}^{2} \\
\text { 沫满- }\end{array}$ & $\begin{array}{l}1000 \mathrm{~m}^{2} \\
\text { 以5 }\end{array}$ & $\begin{array}{l}3000 \mathrm{~m}^{2} \\
\mathcal{L}\end{array}$ & $\begin{array}{l}5000 \mathrm{~m}^{2} \\
\text { 以上 }\end{array}$ & $\begin{array}{l}10000 \\
m^{2} 以 5\end{array}$ & 平均 & $\begin{array}{l}1000 \mathrm{~m}^{2} \\
\text { 来满 }\end{array}$ & $1000 \mathrm{~m}^{2}$ & $3000 \mathrm{~m}^{2}$ & $\begin{array}{l}5000 \mathrm{~m}^{2} \\
\text { 以上 }\end{array}$ & $\begin{array}{l}10000 \\
m^{2} \text { Lt }\end{array}$ & 平均 & $\begin{array}{l}0.000 \mathrm{~m}^{2} \\
\text { 王满 }\end{array}$ & $\begin{array}{l}1000 \mathrm{~m}^{2} \\
\text { Lht }\end{array}$ & $3000 \mathrm{~m}^{2}$ & $\begin{array}{l}50001 \\
\text { 以上 }\end{array}$ & 1000 \\
\hline 新築工事 & 1.94 & 1.33 & 1.33 & 1.42 & 1.52 & 2.76 & 1.94 & 1.33 & 1.3 & 1.42 & 1.5 & 2.76 & 1.94 & & & 1.42 & & 2.76 \\
\hline 電建替工事 & 3.88 & 2.66 & 2.65 & 2.84 & 3.04 & 5.51 & 1.94 & 1.33 & 1.33 & 1.42 & 1.52 & 2.76 & 0.00 & 0.00 & 0.00 & 0.00 & 0.00 & $0: 00$ \\
\hline 気修繥 & 3.03 & 2.03 & 1.97 & 2.15 & 2.43 & 4.86 & 3.03 & 2.03 & 1.97 & 2.15 & 2.43 & 4.86 & 3.03 & 2.03 & 1.97 & 2.15 & 2.43 & 4.86 \\
\hline 設犒修工事 & 1.47 & 0.96 & 0.88 & 1.02 & 1.25 & 2.67 & 4.87. & 3.30 & 3.24 & $3: 51$ & 3.93 & 7.4 & 6. & 4.47 & 4.42 & 4.80 & 5.23 & 9.79 \\
\hline 廃襄処分 & 0.03 & 0.03 & 0.02 & 0.02 & 0.02 & 0.04 & 0.04 & 0.04 & 0.03 & 0.02 & 0.02 & 0.04 & 0.04 & 0.04 & 0.03 & 0.02 & & 0.04 \\
\hline 合 計 & 10.35 & 7.01 & 6.85 & 7.45 & 8.26 & 15.84 & $11: 82$ & 8.03 & 7.90 & 8.52 & 9.42 & 17.88 & 11.58 & 7.87 & 7.75 & 8.39 & $9: 20$ & 17.45 \\
\hline 新葖工事 & 2.45 & 1.22 & 1.41 & 2.00 & 2.13 & 3.13 & 2.45 & 1.22 & 1.41 & 2.00 & 2.13 & 3.13 & 2.45 & 1.22 & 1. & 2.00 & C. & \\
\hline 空建算工事 & 4.91 & 2.45 & 2.81 & 3.99 & 4.26 & 6.26 & 2.45 & 1.22 & 1.41 & 2.00 & 2.13 & 3.13 & 0.00 & 0.00 & 0.00 & 0.00 & 0.00 & 0.00 \\
\hline 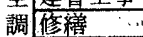 & 6.03 & $3: 11$ & 3.36 & 5.05 & 5.30 & 7.95 & 6.03 & 3.11 & 3.36 & 5.05 & 5.30 & 7.95 & 6.03 & 3.111 & $\sqrt{33}$ & 5.05 & 5.30 & 7.95 \\
\hline 設改修工事 & 6.21 & 3.11 & 3.58 & 4.95 & 5.28 & 7.43 & 8.89 & 4.43 & 5.11 & 7.23 & 7.70 & 10.89 & 11.37 & 5.75 & 6. & 9.16 & 9.69 & 13.2 \\
\hline 廃萭処分 & 0.06 & 0.0 & 0.03 & 0.04 & 0.05 & 0.15 & 0.06 & 0.03 & 0. & 0.05 & 0.05 & 0.14 & 0.06 & 0.03 & & 0.04 & 0.05 & 0. \\
\hline 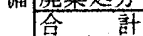 & 19.66 & 9.92 & $\frac{0.09}{11.19}$ & 16.03 & 17.02 & 24.92 & 19.88 & 10.01 & 11.32 & 16.33 & 17.31 & 25.24 & 19.91 & 10.11 & 11.30 & 16.25 & 17.17 & 24.44 \\
\hline 媇築工事 & 1.11 & 1.10 & $0.87^{\prime}$ & 0.95 & 1.15 & 1.30 & 1.11 & 1.10 & 0.87 & 5 & 1.15 & 1.30 & 1.11 & 1.10 & 0. & 0.95 & 1.15 & 1.30 \\
\hline 等工事 & 2.22 & 2.20 & 1 & 1. & 2.29 & 2.60 & 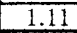 & 1. & 0.87 & 0.95 & 1.15 & 1.3 & 0. & 0.00 & & 0.00 & 0.00 & 0.0 \\
\hline 生修縓 & 2.59 & 2.49 & 2.06 & 2. & 2.76 & 3.09 & 2.59 & 2. & 6 & 2.25 & 2.76 & 3.6 & 2.59 & 2.49 & 2.0 & 2.25 & 2.76 & 3.09 \\
\hline 設改修工事 & 3.14 & 3.03 & 2.51 & 2.77 & 3.32 & & & & & & & & & 4. & & 4 & 4.80 & 5.3 \\
\hline 潇廃雍処分 & 0.08 & 0. & 0.06 & 0 & 0 & 0.09 & 0.08 & 0.09 & 0.06 & 0.06 & 0.0 & 0.0 & 0.07 & 0. & 0. & 0. & 0.0 & 0.08 \\
\hline 合 & 9.14 & 8.92 & 7.25 & 7.94 & 9.59 & 10.90 & 9.07 & 8. & 7.20 & 7.90 & 9.54 & 10. & 8. & $8:$ & 6. & 7. & 8 & $\overline{98}$ \\
\hline 新勧工事 & 0.57 & 0.61 & 0.32 & 0.82 & 0.55 & 0.43 & 0.57 & 0. & $0.3^{3}$ & 0.8 & 0.55 & & & & & & 55 & 0.43 \\
\hline 昇庭替工事 & 1.13 & 1.23 & & & & & & & & 0. & $0:$ & & 0.0 & 0.1 & & 0.0 & 0.00 & 0.00 \\
\hline 降膺 & 1.13 & 1.23 & 0. & & & & 1. & & & & 1. & & & & & & & \\
\hline 機第 & 0.00 & 0.00 & 0.00 & 0.00 & 0.0 & 0.00 & 1.13 & 1.23 & 0. & 1. & 1.10 & 0 & 1.70 & 34 & & 2.46 & 1.65 & 1.30 \\
\hline 設㡾育処分 & 0.01 & 0.01 & 0.01 & 0.01 & .0 .0 & 0.8 & 0.0 & & & 0 & 0.0 & 0. & 0.01 & 0.6 & 0. & 0.1 & 0.01 & . \\
\hline 備合 & 2.84 & 3.08 & 1.63 & 4.11 & 2.76 & 2 & 3.41 & 3.69 & 1.95 & 4. & 3.3 & 2 & 3.41 & 3.6 & 1. & 4.94 & 3.31 & 2.61 \\
\hline
\end{tabular}

表 11 事務所ビルの電気・機械設備の床面積あたり年平均 $\mathrm{LCNOx}\left(\mathrm{g}-\mathrm{NO}_{2} /\right.$ 年 $\left.\mathrm{m}^{2}\right)$

\begin{tabular}{|c|c|c|c|c|c|c|c|c|c|c|c|c|c|c|c|c|c|c|}
\hline & \multicolumn{6}{|c|}{ 建替周期35年 } & \multicolumn{6}{|c|}{ 建替周期50年 } & \multicolumn{6}{|c|}{ 建葜周期100年 } \\
\hline & 平均 & $\begin{array}{l}1000 \mathrm{~m} \\
\text { 未满 }\end{array}$ & $\frac{100 \mathrm{~m}^{2}}{1002}$ & $\begin{array}{l}3000 \mathrm{~m}^{2} \\
\text { 以上 }\end{array}$ & $5000 \mathrm{~m}^{2}$ & $\begin{array}{l}10000 \\
m^{2} 2015\end{array}$ & 酌. & $1000 \mathrm{~m}^{2}$ & $\frac{1000 m^{2}}{1000}$ & $3000 \mathrm{~m}^{2}$ & $5000 \mathrm{~m}^{2}$ & $\begin{array}{l}10000 \\
m^{2} 以 t\end{array}$ & 平场 & $\begin{array}{l}1000 \mathrm{~m}^{2} \\
\text { 满 }\end{array}$ & $1000 \mathrm{~m}^{2}$ & $3000 \mathrm{~m}^{2}$ & $5000 \mathrm{~m}^{2}$ & $\begin{array}{l}10000 \\
m^{2} M 5\end{array}$ \\
\hline 噺勧工事 & 2.89 & $\frac{500}{2.00}$ & $\frac{1}{1.98}$ & $\frac{1.08}{2.08}$ & 2.23 & $\frac{1}{1.4 .05}$ & 2.89 & $\begin{array}{l}2.00 \\
\end{array}$ & $\frac{f}{1.98}$ & $\frac{1.08}{2.08}$ & $\frac{1}{2.23}$ & $\frac{1.05}{4.05}$ & 2.89 & $\frac{2.00}{2.00}$ & 1.98 & 2.08 & 2.23 & 4.05 \\
\hline 電揵替工事 & 5.77 & 4.00 & 3.95 & 4.17 & 4.45 & 8.09 & 2.89 & 2.00 & 1.98 & 2.08 & 2.23 & & 0.00 & 0.00 & 0.00 & & 0.00 & 0.00 \\
\hline 気修絋 & 4.76 & 3.24 & 3.11 & 3.34 & 3.75 & 7.39 & 4.76 & 3.24 & 3.11 & 3.34 & 3.75 & 7.39 & 4.76 & 3.2 & 3 & 3.34 & 3.75 & 7.3 \\
\hline 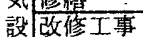 & $\frac{4.10}{2.38}$ & $\frac{.24}{1.56}$ & $\frac{0.12}{1.44}$ & 1.64 & $\frac{0.90}{1.99}$ & 4.18 & 7.38 & 5.04 & 4.91 & 5.26 & 5.86 & 11.13 & 9.85 & 6.78 & 6.64 & 7.12 & 7.71 & 14.50 \\
\hline 備廃寨処分 & 0.08 & 0.07 & 0.05 & 0.05 & 0.05 & 0.08 & 0.09 & 0.08 & 0.06 & 0.05 & 0.05 & 0.10 & 0.09 & 0.0 & 0.06 & 0.05 & & \\
\hline 合 計 & 15.88 & 10.87 & 10.53 & 11.28 & 12.47 & 23.79 & 18.01 & 12.36 & 12.04 & 12.81 & 14.12 & 26.72 & 17.59 & 12.10 & 11.79 & 12.59 & 13.74 & 26.03 \\
\hline 薪築工事 & $3: 50$ & 1.72 & 1.98 & 2.87 & 3.05 & 4.77 & 3.50 & 1.72 & 1.98 & 2.87 & 3.05 & 4.77 & 3.50 & 1.72 & 1.98 & 2.87 & 3.05 & 4.77 \\
\hline 架 建替工事 & 7.01 & 3.43 & 3.96 & 5.74 & 6.11 & 9.53 & 3.50 & 1.72 & 1.98 & 2.87 & 3.05 & 4.77 & 0.00 & 0.00 & 0.00 & 0.00 & 0.00 & 0.0 \\
\hline 櫊修櫭 & 8.01 & 4.02 & 4.43 & 6.75 & 7.08 & 11.16 & 8.01 & 4.02 & 4.43 & 6.75 & 7.08 & 11.16 & 8.01 & 4.02 & 4.43 & 6.75 & 7.08 & 11.16 \\
\hline 設改修工事 & 8.78 & 4.32 & 4.96 & 7.13 & 7.54 & 11.07 & 12.51 & 6.10 & 7.06 & 10.3 & 10.95 & 16.09 & & 8 & 9.09 & 13.1 & 13.81 & \\
\hline 備廃衰处分 & 0.13 & 0.06 & 0.07 & 0.10 & 0.10 & 0.33 & 0.13 & 0.06 & 0.07 & 0.10 & 0.11 & 0.30 & 0.1 & 0.06 & 0.07 & 0.10 & 0.10 & 0.32 \\
\hline 合 計 & 27.43 & 13.55 & 15.40 & 22.59 & 23.88 & 36.86 & 27.65 & 13.62 & 15.52 & 22.94 & 24.24 & 37.09 & 27.75 & 13.83 & 15.57 & 22.84 & 24.04 & 35.95 \\
\hline 新築工事 & 1.89 & $\frac{1.93}{1.93}$ & $\frac{1.49}{1.49}$ & 1.59 & 1.92 & 2.15 & 1.89 & 1.93 & $\frac{1.49}{1.49}$ & 1.59 & 1.92 & 2.15 & 1.89 & 1.8 & 1.49 & 1.59 & 1.92 & 2.1 \\
\hline I事 & 3.78 & 3.86 & 2.98 & 3.19 & 3.85 & $4: 30$ & 1.89 & 1.93 & 1.49 & 1.59 & 1.92 & 2.15 & 0.00 & 0.00 & 0.0 & 0.00 & 0.00 & 0.00 \\
\hline 生修繬 & 4.09 & 4.08 & 3.25 & 3.49 & 4.26 & 4. & 4.09 & 4 & 3.25 & 3.49 & 4.26 & 4.70 & 4.09 & 4.08 & 3.25 & 3.49 & 4.26 & 4.7 \\
\hline 設政修工事 & 5.19 & 5.05 & $4: 17$ & 4.54 & 5.45 & 6 & 6.90 & 6.65 & 5.53 & $\mathrm{~b}$ & 7. & 8.13 & 70 & 7.7 & & 6. & 7.9 & 8. \\
\hline 裹处分 & 0.17 & 0.23 & 0.13 & 0.13 & 0.16 & 0.1 & 0.17 & 0. & 0.13 & 0. & & 0.18 & 0. & 0. & & 0. & 0.15 & \\
\hline & $\frac{0.1}{15.12}$ & 15.15 & $\frac{0.10}{12.02}$ & $\frac{0.10}{12.94}$ & $\frac{0.10}{15.64}$ & $\frac{1 .}{17.5}$ & $\frac{.14}{14.94}$ & 14.80 & 11.89 & 12.83 & 15.47 & 17.31 & $13:$ & 13.93 & 0. & 11.80 & 14.23 & 15.76 \\
\hline 薪算 & 0.96 & 1.04 & 0.55 & 1.39 & $0.93^{\circ}$ & 0.74 & 0.96 & 1.04 & 0.55 & 1.39 & & 0.74 & 0 & 4 & & & 0.93 & 0. \\
\hline 替工事事 & 1.92 & 2.0 & 1.10 & 2.78 & 1. & 1. & 0 & 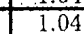 & 0. & 1.39 & 0 & 0.7 & 0 & 0. & 0 & 0.00 & 0.00 & 0.00 \\
\hline 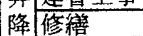 & 1.92 & 2.08 & 1.10 & $\therefore 2: 7$ & 1. & & & & 1. & & & 1. & & & 1. & 2.78 & 1.86 & 1.47 \\
\hline 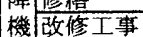 & 0.00 & $\frac{2.00}{0.00}$ & 0.00 & $\frac{0.6}{0.1}$ & 0. & $\frac{1}{0}$ & 4 & 2.0 & 1 & 2. & & 1. & 2 & 3 & I & & & \\
\hline 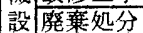 & 0.02 & 0.02 & 0.01 & 0. & 0. & 0.0 & 0 & & 0. & 0. & 0. & 0.0 & 0. & 0.0 & 0.0 & 0. & 0.02 & 0.1 \\
\hline 備念 & 4.82 & 5.22 & 2.76 & 6.9 & 4 & 3.70 & 5.7 & 6. & & 8.3 & 5.6 & 4.44 & 5.77 & 6.26 & 3.31 & 8.37 & 5.59 & 4.44 \\
\hline
\end{tabular}

表 12 事務所ビルの電気・機械設備の床面積あたり年平均 LCE (MJ/年 $\left.\mathrm{m}^{2}\right)$

\begin{tabular}{|c|c|c|c|c|c|c|c|c|c|c|c|c|c|c|c|c|c|c|}
\hline & \multicolumn{6}{|c|}{ 唓智周期35年. } & \multicolumn{6}{|c|}{ 途智周期50年 } & \multicolumn{6}{|c|}{ 建柏居期 100 年 } \\
\hline & 平苗 & $1000 \mathrm{~m}^{22}$ & $\begin{array}{l}1000 \mathrm{~m}^{2} \\
15\end{array}$ & $3000 \mathrm{~m}^{2}$ & $\begin{array}{l}5000 \mathrm{~m}^{2} \\
\text { 以上 }\end{array}$ & $\begin{array}{l}10000 \\
m^{2} 55\end{array}$ & 平均 & $\begin{array}{l}1000 \mathrm{~m}^{2} \\
\text { 来溚 }\end{array}$ & $\begin{array}{l}1000 \mathrm{~m}^{2} \\
\text { 以上 }\end{array}$ & $\begin{array}{l}3000 \mathrm{~m}^{2} \\
\text { L上 }\end{array}$ & $\begin{array}{l}5000 \mathrm{~m}^{2} \\
\text { 以.上. }\end{array}$ & $\begin{array}{l}10000 \\
\mathrm{~m}^{2} \text { 以上 }\end{array}$ & 平均 & \begin{tabular}{|l|}
$1000 \mathrm{~m}^{2}$ \\
梁满
\end{tabular} & $\begin{array}{l}1000 \mathrm{~m}^{2} \\
1 \mathrm{~L}-\end{array}$ & $\begin{array}{l}3000 \mathrm{~m}^{2} \\
\text { L2 }\end{array}$ & $\begin{array}{l}5000 \\
215 \\
21\end{array}$ & 等以. \\
\hline 新筑工事 & .13 & 43 & -12.17 & -13.27 & 14.32 & 26.60 & $18: 13$ & 12.4 & & $13: 27$ & 14.32 & 26.60 & 18.13 & 12.43 & 12.17 & 13.27 & 14.32 & 26.60 \\
\hline 電建替工事 & 36.27 & 24.86 & 24.35 & 26.54 & 28.64 & 53.19 & 18.13 & 12.43 & 12.17 & 13.27 & 14. & 26.60 & & & & & & \\
\hline & 32.79 & 2.23 & 21.20 & 23.35 & 26.24 & 51.30 & 32.79 & 22.23 & 21120 & 23.35 & 26.24 & 51.30 & 32.79 & 22. & 21 & & 56 & 51 \\
\hline 設啟敒工事 & 16.78 & 10.94 & 9.96 & 11.72 & & & 47.65 & 32.15 & 30.99 & 34.35 & $38: 94$ & 75.90 & 63.10 & 42.82 & 41.57 & 46.21 & 50.89 & 98.51 \\
\hline 備廃衰赺分 & 0.25 & 0.23 & 0.18 & 0.15 & 0.15 & 0.28 & 0.29 & 0.28 & 0.21 & 0.18 & 0.18 & 0.32 & 0.29 & 0.27 & 0.21 & 0. & & \\
\hline 合 - - 䚵 & $04: 22$ & 70.69 & 67.86 & 75.03 & 83.83 & 62.45 & 116.99 & 79.52 & 76.74 & 84.42. & 94.00 & $80.72^{\circ}$ & 114.31 & 77.75 & 75.15 & 83.01 & 91.62 & 76.72 \\
\hline 新桑工事 & 21.81 & 10.73 & 12.35 & 17.87 & $18: 96$ & 28.61 & 21.81 & 10.7 & 12.35 & 17.8 & & 20.0 & 21.8 & 10.73 & 2.35 & 1787 & 18.96 & 28.61 \\
\hline 空建替工事 & 43.62 & $21: 47$ & 24.70 & 35.75 & 37.92 & $57: 22$ & 21.81 & 10.73 & 12.35 & 17.87 & 18.96 & 28.61 & 0.00 & 0.00 . & 0.00 & 0.00 & 0.00 & 0.00 \\
\hline dix & 50.16 & $25.34:$ & 27.84 & 41.97 & 44.00 & 67.16 & 70 & 25.34 & 27.84 & 41.97 & 44.00 & 67.16 & 50.16 & 25.34 & 27.84 & 41.97 & 44.00 & 67.16 \\
\hline 設改傑工事 & 57.06 & 28.24 & 32.39 & 46.14 & 48.79 & 70.03 & 80.39 & 39.53 & 45.57 & 66.01 & 69.81 & $100: 44$ & 04.30 & 52.34 & 59.02 & 44.53 & & 22.95 \\
\hline 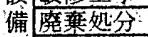 & 0.44 & 0.21 & 0.23 & 0.32 & 0.34 & 11.07 & 0.43 & 0.20 & 0.23 & 0.33 & 0.35 & 0.98 & 0.44 & 0.2 & 0.23 & 0.32 & 0.34 & 1.05 \\
\hline 合 計 & 73.09 & 85.99 & 97.51 & 42.05 & 50.01 & 24.09 & 74.60 & 86.53 & 98.34 & 144.05 & 2.08 & 25.80 & 176.71 & 88.62 & 99.44 & 44.69 & 52.20 & 9.77 \\
\hline 新築王事 & 10.96 & 10.91 & 8.69 & 9.36 & 11.09 & 12.44 & 10.96 & 10.91 & 8.69 & 9.36 & .11 .09 & .12 .44 & $10.96^{4}$ & $\overline{109}$ & 8.69 & 9.36 & .09 & $2: 44$ \\
\hline 衛建替工事 & $\frac{10.90}{21.91}$ & $\frac{10.11}{21.82}$ & $17: 38$ & 18.71 & 22.19 & 24.88 & 10.96 & & & 9.36 & & & 0.00 & & & & 0.00 & 0.00 \\
\hline 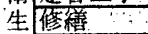 & 24.07 & 23.48 & 19.20 & 20.71 & 24.93 & 27.73 & 24.07 & 23.48 & 9.20 & 20.71 & 24. & 7. & 24.07 & 3.48 & 19.20 & 20.71 & 24.93 & 27.73 \\
\hline 設啟修工事 & $30: 1$ & 29.05 & 24.19 & 26.49 & 31.33 & 36.22 & 40. & 38.81 & 32.67 & 35 & 42.14 & 48 & 45.52 & 44.8 & 8642 & 39.22 & 46.29 & 51.6 \\
\hline 倫廃裹処分 & 0.57 & 0.74 & 0.44 & 0.41 & 0.52 & 0.62 & 0.55 & 0.68 & 0.42 & 0.40 & 0.50 & & 0. & & & 0.38 & 040 & 0.57 \\
\hline 許 & 87.62 & 86.00 & 69.90 & 75.68 & 90.06 & 01189 & $87.26^{\circ}$ & 84.85 & 69.67 & 75.58 & $89: 75$ & 01 & 81.0 & 79.9 & 64. & & 80 & .39 \\
\hline 新篍工事 & 5.81 & $.6 .29^{\prime}$ & 3.32 & & $5: 62$ & 4.46 & $.5 .81^{11}$ & 6.29 & .3 .2 & 8. & 5.6 & & & & & 8 & 98 & 4.4 \\
\hline 昇建替工事 & $11: 6$ & 12.58 & 6.65 & $16: 85$ & 11.25 & 8.91 & 5.81 & 9 & & 8 & & & & & & & & \\
\hline$\sqrt{4}$ & 1.61 & 12.58 & 6.65 & 16.85 & 11.25 & & 11. & 12. & & 16. & 11 & 8.9 & 1.8 & 12. & 6. & 16. & & \\
\hline 機改修工事 & 0.00 & 0.00 & 0.00 & 0. & 0. & 0 & 11. & 12. & 6.6 & 16 & 1.1 & & 17. & & & & & \\
\hline & 0.06 & & 0 & & 0.06 & & 0.0 & Wo & & & & & 0.08 & 0.0 & & & 0.07 & 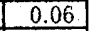 \\
\hline & 9.09 & & & & & & $2 \pi$ & & & & & 5 & & & 9.08 & 5065 & 881 & 80 \\
\hline
\end{tabular}




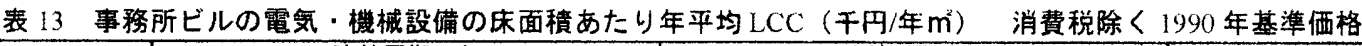

\begin{tabular}{|c|c|c|c|c|c|c|c|c|c|c|c|c|c|c|c|c|c|c|}
\hline & \multicolumn{6}{|c|}{ 替周期35年 } & \multicolumn{6}{|c|}{ 建替周期50年 } & \multicolumn{6}{|c|}{ 建替周期 100 年 } \\
\hline & 西 & $\begin{array}{l}100 \mathrm{~m}^{2} \\
\text { 本满 }\end{array}$ & $\begin{array}{l}0.100 \mathrm{~m}^{2} \\
\mathrm{~W}^{2}\end{array}$ & $\begin{array}{l}3000 \mathrm{~m}^{2} \\
\mathrm{~W}\end{array}$ & {$\left[\begin{array}{l}5000 \mathrm{~m}^{2} \\
以 \quad \text {. }\end{array}\right.$} & $\begin{array}{l}10000 \\
n^{2} 以 5\end{array}$ & 均 & $\begin{array}{l}1000 \mathrm{~m}^{2} \\
\text { 涌 }\end{array}$ & $\begin{array}{l}1000 \mathrm{~m}^{2} \\
\mathrm{~W}\end{array}$ & $\begin{array}{l}3000 \mathrm{~m}^{2} \\
255\end{array}$ & $\begin{array}{l}5000 \mathrm{~m}^{3} \\
\text { 以上 }\end{array}$ & $\begin{array}{l}10000 \\
m^{2} \uplus 5\end{array}$ & 均 & $\begin{array}{l}1000 \mathrm{~m}^{2} \\
\text { 满 }\end{array}$ & $\begin{array}{ll}000 \mathrm{~m}^{2} \\
\mathrm{c}\end{array}$ & $\begin{array}{l}3000 \mathrm{~m}^{2} \\
\text { 以上 }\end{array}$ & $\begin{array}{l}5000 \mathrm{~m}^{3} \\
\text { 以上 }\end{array}$ & $\begin{array}{l}10000 \\
\mathrm{~m}^{2} \mathrm{~W} \text { 上 }\end{array}$ \\
\hline 制築工事 & 0.40 & 0.28 & 0.27 & 0.31 & & 0.53 & 0.40 & & 0.27 & 0.31 & 0.31 & 0.53 & 0.40 & & 0.27 & 0.31 & 0.31 & 0.53 \\
\hline 電犍替工事 & 0.79 & 0.56 & 0.54 & 0.62 & 0.61 & 1.06 & 0.40 & 0.28 & 0.27 & 0.31 & 0.31 & 0.53 & 0.00 & 0.00 & 0.00 & $\frac{0.01}{0.00}$ & 0.00 & 0.00 \\
\hline 気修縉 & 0.55 & 0.40 & 0.36 & 0.40 & 0.44 & 0.82 & 0.55 & 0.40 & 0.36 & 0.40 & 0 & 0.82 & 0.55 & 0.40 & 0.36 & 0.40 & 0.44 & \\
\hline 設改修工事 & & & 0.18 & & & & 0.72 & 51 & 0.47 & 0.53 & 0.60 & 1.14 & 0.94 & 67 & 0.62 & .71 & 0.77 & $\frac{1.50}{1.50}$ \\
\hline 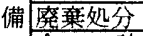 & 0.00 & 0.00 & 0.00 & 0.00 & 0.00 & 0.00 & 0.00 & 0.00 & 0.00 & 0.00 & 0.00 & 0.00 & 0.00 & 0.00 & 0.00 & 0.00 & 0.00 & 0.00 \\
\hline & 2.03 & 1.44 & 1.35 & 1.54 & 1.60 & 2.92 & 2.07 & & 137 & 1.55 & 1.66 & 3.03 & 1.89 & & 125 & 1.42 & 1.52 & \\
\hline 堷築工事 & 0.43 & 0.23 & 0.25 & 0.37 & 0.38 & 0.54 & 0.43 & 0.23 & 0.25 & 0.37 & 0.38 & 0.54 & 0.43 & 0.23 & 0.25 & 0.37 & 0.38 & 0.54 \\
\hline 品建替工事 & 0.86 & 0.45 & 0.50 & 0.75 & 0.76 & 1.08 & 0.43 & 0.23 & 0.2 & 0.37 & 0.38 & & & & & & & 0.0 \\
\hline 調應綣 & 0.87 & 0.48 & 0.49 & 0.77 & 0.80 & 1.16 & 0.87 & 0.48 & 0.49 & 0.77 & 0.80 & 1.1 & 0.87 & 0.4 & .4 & 0.77 & 0.80 & .1 \\
\hline 設政修工事 & 0.80 & 0.42 & 0.46 & 0.65 & 0.68 & 0.92 & 1.20 & 0.62 & 0.70 & 1.01 & 1.06 & $\frac{1.14}{1.46}$ & $\frac{0.06}{1.58}$ & 0.83 & 0.92 & $\frac{0.61}{1.31}$ & $\frac{0.00}{1.36}$ & 1.80 \\
\hline 䚚廃重処分 & 0.01 & 0.00 & 0.00 & 0.00 & 0.00 & 0. & 0.00 & 0.00 & 0.00 & 0.00 & 0.00 & 0.01 & 0.01 & 0.0 & 0.00 & 0.00 & 0.00 & $\frac{1.01}{0.01}$ \\
\hline 合 & 2.97 & 1.58 & 1.70 & 2.54 & 62 & 3.7 & 2.93 & 1.56 & 1.69 & 2.5 & & 3.71 & 2.89 & 54 & 6 & 2.45 & $\frac{2.54}{2.54}$ & 3.5 \\
\hline 新筑工事 & 0.18 & 0.19 & 0.14 & 0.15 & 0.18 & 0.21 & 0.18 & 0.19 & 0.14 & 0.1 & 0. & 0.2 & 0.1 & 0.1 & 0.1 & 0.1 & 0.1 & 0.2 \\
\hline 衛揵秏工事 & 0.36 & 0.37 & 0.28 & 30 & 0.36 & 0.41 & 0.18 & 0.19 & 0.14 & 0. & 0. & 0.21 & 0.0 & 0.0 & 0.00 & 0.00 & 0.00 & 0.00 \\
\hline 生䧹縉 & & 0.3 & 0.26 & 0.26 & 0.33 & & 0.31 & 0. & 0. & 0.26 & & 0.35 & & & 0.26 & 0.26 & 0.33 & 0.35 \\
\hline 設啟修工事 & 0.33 & 0.35 & 0.27 & 0.28 & 0.34 & 0.39 & 0.45 & 0.4 & 0.3 & & & 0.5 & 0.5 & & 0.4 & 8 & 0.52 & 0.56 \\
\hline 倫㡠董起分 & 0.01 & 0.01 & 0.01 & 0.00 & 0.01 & 0. & 0.01 & & & 0 & & & & & & 0 & 51 & 0.01 \\
\hline 合 & $\frac{1.19}{1.19}$ & 1.24 & 0.96 & 0.99 & $\frac{\frac{0.12}{1.22}}{1}$ & $\frac{0.3}{1.3}$ & $\frac{0.01}{1.13}$ & 1.18 & $\frac{.01}{0.92}$ & 0.94 & $\frac{0.01}{1.16}$ & 1.2 & $\frac{0.0}{1.0}$ & 1.0 & $\frac{0.01}{0.83}$ & 0.84 & $\frac{0.01}{1.04}$ & 0. \\
\hline 薪築工事 & 0.29 & 0.32 & 0.17 & 0. & & & 0.29 & & & 0.4 & & & 0. & & 0.1 & 0.42 & & \\
\hline 舁建替工事 & & 0. & 0. & & 0. & 0 & 0. & 0. & 0. & 0. & & & 0. & 0.0 & 0 . & 0.00 & 00 & 0.00 \\
\hline 修䋛 & 0.58 & 0.65 & 0.34 & 0.84 & 0.56 & 0.44 & 0.58 & 0.6 & 0.3 & & 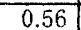 & & & & & & & \\
\hline 機敀修工事 & 0.00 & 0.00 & 0.00 & 0.0 & 0. & 0.00 & 0.5 & 0.6 & 0.3 & 0.8 & 0.5 & & 0.8 & 0.9 & 0.51 & 1.26 & 0.84 & 0.66 \\
\hline 設廃㲤処分 & 0.00 & 0.00 & 0.00 & 0.00 & 0.00 & 0.00 & 0.00 & 0.00 & 0.00 & 0.00 & 0.00 & 0.00 & 0.00 & 0.00 & 0.00 & 0.00 & $\frac{0.07}{0.00}$ & 0.00 \\
\hline 備答 & 1.45 & 1.62 & 0.85 & 2.10 & 1.40 & 1.10 & 1.74 & 1.94 & 1.02 & 2.52 & $\frac{.08}{1.68}$ & & $\frac{0.74}{1.74}$ & $\frac{0.00}{1.94}$ & $\frac{02}{1.02}$ & $\frac{0.00}{2.52}$ & $\frac{0.00}{1.68}$ & 0.0 \\
\hline
\end{tabular}

筆者らは、1990 年産業連関表を利用して、建築設備関連資材の $\mathrm{CO}_{2} 、 \mathrm{SOx} 、 \mathrm{NOx} 、$ エネルギー原単位を、国内分／海外分、消費 支出分／固定資本形成分、生産段階分／流通段階分別に分析した結 果を示した。また、事務所ビル規模別工事·奏績統副及び建設部門产: 業連関表等を利用して、奏用的な LCA 手法に利用するための電気・ 空調・衛生・昇降機設備の $\mathrm{LCCO}_{2} 、 \mathrm{LCSO} \mathrm{x} 、 \mathrm{LCNO} \mathrm{x} 、 \mathrm{LCE}$ 原単. 位を示した。今後、店舗、学校、病院、ホテル、集合住宅などの他 用途、また、水質污䖲、産業廃棄物等についも同様の原単位整備 してゆく予定である。

\section{謝 辞}

本研究の遂行にあたり、(財)電力中央研究所の内山洋司氏、本藤 袏樹氏より産業部門別直接環境負荷データの提供をはじめ、さまざ まなご協力を頂いた。また、(社)日本建築学会地球環境委員会 LCA 指針策定小委貝会(石福 昭主査)、(社)空気調和・衛生工学会地球環

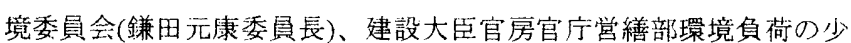
ない官庁施設の整備手法の㭘討委員会(松尾陽委員長、城本雄三専 門委員長)、(財)住:宅・建築省エネルギー機構 IEA/Annex31 国内委員 会(岡 建雄委員長)、(社)珄業環境管理協会 LCA 奏務入門編集委員 会(稲葉 敦委員長)では、委員の方々より多くの示唆を頂いた。さ らに、(株)日建設計より研究助成のための奨学奇附を頂いた。記し て謝意を表するる次第である。

\section{参考文献}

1) 日本建築学会建築之地球糫境委員会特別研究委員会：建築が地球環境に 与える影響、1 1992.6

2）日本建築学会地球環境委員会ライフサイクル $\mathrm{CO}_{2}$ 小委員会：ライフサイ クル CO,で建物を測る、1996.3

3) 日本建築学会地球環境委䝿会 LCA 指針策定小委員会：建物の LCA 指針 案、1998.11

4) 竹林芳久、岡建雄、紺矢哲夫：座業連関表による建築物の評価、その2 事務所建筑の建設に上る璔境への影響、日本建築学会計画系論文報告集 $N_{0} 431,1992.1$

5）伊香贺俊治、松縄 堅ほか：建築・都市づくりにおける環境負荷の削減 に関守万研究、その2. 地球温暖化抑制の可能性に関する検討、日本建藇 学会大会学術講演梗概集 (環境系)、pp. 1329 1330、1992.8

6）鈴木道哉、岡 建雄、岡田表更、矢野謙襀：産業連関表による建築物の

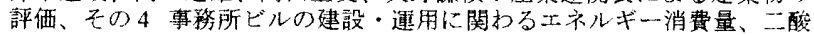
化炭素排出量、日本建築学会郭面系論文報告集№.476、pp.37 43、1994.9
7) 伊香賀俊治：建築設備分野のライフサイクル $\mathrm{CO}$ に迀地球環境評価、 日本学術会議第 10 回環境工学連合楛演会講演論文集、pp. 1 8、1995.1 8）井上隆ほか：地球鼬暖化対策としての住宅の省エネルギー手法の評価、 その 1、日本建築学会大会学術集演梗概集 (環境系)、pp.871 872、1995.8

9) 伊香賀俊治、外阙 曹、石福 昭: 建物のライフサイクル $\mathrm{CO}_{2}$ 分析用 $\mathrm{CO}$ 原単位以関古万研究，之の 1. 産業連関分析に上る消費支出上盗本形成分

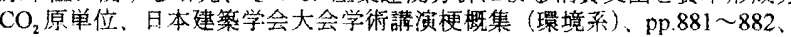
1995.8

10) 酒井筧二、漆崎 昇、相賀 洋、下山真人：建築物のライフサイクル二 酸化炭素排出量とその抑制方策に関する研究、日本建築学会計画系諭文 集 No.484、pp.105 112、1996.6

11) 佐藤正章、岡田幸雄：基本設計段階でのライフサイクル評価システムに 関す万研究、その 1 ，概算見積システムと建郡分の $\mathrm{CO}_{2}$ 排出量の評価シ ステムの連携、日本建築学会大会学術講演梗概集（環境系），pp.885～886、 1996.9

12) 近藤美則、森口絠一編著：産業連関表に上る二酸化炭素排出原算位、環 境庁国立環境研究所 地球環境研究センター、1997.3

13）小王祐一郎、澤地孝男、中岛史郎：建築のシイフサイクルエネルギ一算 出プログラムマニュアル、建設省建築研究所、1997.11

14）本藤祐樹、外阊 豊、内山洋二：産業連関表を用いた我が国の生産活動 に伴う境負荷の実態分析、電力中央研究所報告 Y97017、1998.6

15) 伊香賀俊治、外岡 豊、石福 昭：建物の LCA データベースに関する研 究、その1．1990年産業連関表を利用したエネルギ一、CO

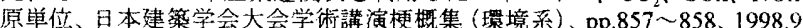

16) 林英明、岡 建雄、小玉祐一郎：1990 年表による视灴”一消費量と炭瑟排出 量の原笚位、産業連関表に上る建築物の詊価 (その5)、日本建築举会計 画系論文集 No.511、pp.75 81、1998.9

17) Toshiharu Ikaga Yutaka Tonooka and Hiroki Hondo Development of Data Base for Life Cycle Assessment of Buildings(Part 3 ), Proceedings of The Third International Conference on Eco Balance, pp.365-368, 1998.11

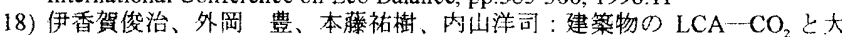
気污染排出評価、第 15 回エネルギーシステム・経済・環境コンファレン 又講演論文集、pp.425 430、1999.1

19) 総務打：平成 2 年産業連関婊、(財) 全国統㖕協会連合会、1994.3

20 ) 建設省建設経済刷監修: 平成 2 年建設部門分析用産業連関表、(財)建設物 洒調查会、1995.1

21）建設大臣官鬲官打営繥部監修：建築物のライフサイクルコスト、(財)経済 調查会、1993

22) (社)建築・設備維持保全推進協会編著：ビルディングLC ビジネス百科、 才一ム社、1996.6

23）建設工業経営研究会編著：建築工事原価分析情報、大成出版社、1997.4

24）建設工業経営研究会編著：標滩建築費指数及び施工単価月報、大成出版 社、1991.1 1996.

25)(財)建設物価調查会積算委員会編：改訂 34 版 建設工事標準步掛、(財) 建設物価調查会、1997.9

26）建設大臣官房官庁営眯部監修：[平成 9 年基準]建設省建築工事積算基鹤の 解説、(財)建筑コス卜管理シス云公研究所、1998.2

27）建設大臣官房宫庁営䋛部監修、グリーン广含計画指針及び同解説 平成 11 年、(社) 公洪建築協会、1999.4

28）野城智也、加藤裕久、吉田倬郎、小松幸夫：東京都中央区に招计万事務 所建築の寿命実態、日本建築学会副画系論文報告集№413、1990.7

29）空気調和・衛生工学会地球㜯境委員会：建築設備之地球環境汇関する研 究、1999.3

30）（社）産業環境管理協会 LCA 実務入門編集委員会編：LCA 実務入門、丸善、 1998.8 